\title{
Some Important Metabolites Produced by Lactic Acid Bacteria Originated from Kimchi
}

\author{
Se-Jin Lee ${ }^{1}$, Hye-Sung Jeon ${ }^{1}$, Ji-Yeon Yoo $^{1}$ and Jeong-Hwan Kim ${ }^{1,2, *}$ \\ 1 Division of Applied Life Science (BK21 Four), Graduate School, Gyeongsang National University, \\ Jinju 52828, Korea; tpwls5151@naver.com (S.-J.L.); hye4098@naver.com (H.-S.J.); u6183@naver.com (J.-Y.Y.) \\ 2 Institute of Agriculture and Life Science, Gyeongsang National University, Jinju 52828, Korea \\ * Correspondence: jeonghkm@gnu.ac.kr
}

Citation: Lee, S.-J.; Jeon, H.-S.; Yoo, J.-Y.; Kim, J.-H. Some Important Metabolites Produced by Lactic Acid Bacteria Originated from Kimchi. Foods 2021, 10, 2148. https:/ / doi.org/10.3390/foods10092148

Academic Editor: Eugenio Parente

Received: 19 July 2021

Accepted: 7 September 2021

Published: 10 September 2021

Publisher's Note: MDPI stays neutral with regard to jurisdictional claims in published maps and institutional affiliations.

Copyright: (c) 2021 by the authors. Licensee MDPI, Basel, Switzerland. This article is an open access article distributed under the terms and conditions of the Creative Commons Attribution (CC BY) license (https:// creativecommons.org/licenses/by/ $4.0 /)$.

\begin{abstract}
Lactic acid bacteria (LAB) have been used for various food fermentations for thousands of years. Recently, LAB are receiving increased attention due to their great potential as probiotics for man and animals, and also as cell factories for producing enzymes, antibodies, vitamins, exopolysaccharides, and various feedstocks. LAB are safe organisms with GRAS (generally recognized as safe) status and possess relatively simple metabolic pathways easily subjected to modifications. However, relatively few studies have been carried out on LAB inhabiting plants compared to dairy LAB. Kimchi is a Korean traditional fermented vegetable, and its fermentation is carried out by LAB inhabiting plant raw materials of kimchi. Kimchi represents a model food with low $\mathrm{pH}$ and is fermented at low temperatures and in anaerobic environments. LAB have been adjusting to kimchi environments, and produce various metabolites such as bacteriocins, $\gamma$-aminobutyric acid, ornithine, exopolysaccharides, mannitol, etc. as products of metabolic efforts to adjust to the environments. The metabolites also contribute to the known health-promoting effects of kimchi. Due to the recent progress in multi-omics technologies, identification of genes and gene products responsible for the synthesis of functional metabolites becomes easier than before. With the aid of tools of metabolic engineering and synthetic biology, it can be envisioned that LAB strains producing valuable metabolites in large quantities will be constructed and used as starters for foods and probiotics for improving human health. Such LAB strains can also be useful as production hosts for value-added products for food, feed, and pharmaceutical industries. In this review, recent findings on the selected metabolites produced by kimchi LAB are discussed, and the potentials of metabolites will be mentioned.
\end{abstract}

Keywords: kimchi; kimchi LAB; metabolites; bacteriocins; GABA; ornithine; mannitol; exopolysaccharides; 2-hydroxyisocaproic acid; 3-phenyllactic acid

\section{Introduction}

Kimchi is a traditional Korean vegetable food produced through fermentation carried out by lactic acid bacteria (LAB) originated from the raw ingredients of kimchi [1,2]. The major ingredients of kimchi are baechu (kimchi cabbage), radish, cucumber, and other vegetables, and baechu kimchi is the most common and popular type of kimchi in Korea. Other minor ingredients are added as seasoning, and they include chives, garlic, red pepper powder, ginger, leek, green onion, salt, and jeotgal (salted and fermented seafood) or aekjeot (liquid-type jeotgal, similar to fish sauce). The minor ingredients are first mixed together, and then added to baechu previously salted in brine overnight and washed with tap water. Depending on provinces and personal preferences, other vegetables or fruits such as pear are added [3]. A typical composition of baechu kimchi is as follows: the salted bachu $(100 \%)$ is mixed with radish $(13 \%)$, red pepper powder $(3.5 \%)$, garlic $(1.4 \%)$, ginger $(0.6 \%)$, aekjeot $(2.2 \%)$, sugar $(1.0 \%)$, and green onion $(2 \%)$ [3]. The final salt level is around $2.5 \%$. Various biofunctional compounds are present in kimchi, and they are derived from either the raw materials themselves or the metabolic activities of LAB during fermentation. 
Kimchi fermentation is started by LAB originated from raw ingredients, and garlic is the most important source [2]. Ginger and leek are also important sources, whereas baechu contains a low number of LAB [2]. Fermentation proceeds at a refrigerating temp. between $-1{ }^{\circ} \mathrm{C}$ and $7{ }^{\circ} \mathrm{C}$ for several months. During fermentation, various LAB species proliferate in sequence and produce metabolites such as organic acids (lactic and acetic acid), amino acids, exopolysaccharides, vitamins, mannitol, bacteriocins, etc., and many of them possess health-promoting effects such as antioxidative, anticancer, reduction in total cholesterol, and anti-inflammatory effects [3-5]. The major metabolites produced by LAB through lactic fermentation are either exclusively lactic acid (homo lactic fermentation) or mixture of lactic acid, ethanol, acetic acid, and $\mathrm{CO}_{2}$ (hetero lactic fermentation), depending on the species. Other minor compounds such as $\gamma$-aminobutyric acid (GABA), ornithine, mannitol, exopolysaccharide (EPS), 2-hydroxyisocaproic acid (HICA) and 3-phenyllactic acid (PLA) are derived from amino acids or sugars by enzyme activities of LAB. The production of some compounds helps LAB hosts to adjust to adverse environments. GABA and mannitol are the examples (see below).

Kimchi fermentation is carried out naturally without starters in most cases, but the use of starters is on the rise recently as the demand for the production of kimchi with consistent quality in an industrial scale becomes important [1]. The quality of kimchi is affected by many factors, including types and ratios of raw materials used and fermentation conditions (temp., $\mathrm{pH}$, salt concentration). Diverse LAB species become dominant at different stages of kimchi fermentation, and the fermentation conditions vary widely. The most important groups of LAB are Leuconostoc, Lactobacillus, and Weissella, and they include Leuconostoc mesenteroides, Leuconostoc citreum, Leuconostoc gelidium, Lactobacillus brevis (now, Levilactobacillus brevis), Lactobacillus plantarum (now, Lactiplantibacillus plantarum), Lactobacillus sakei (now, Latilactobacillus sakei), Weissella confusa, Weissella koreensis, and Weissella cibaria [6-8]. Due to the rapid progress in next-generation sequencing and multi-omics technologies including metagenomics, metatranscriptomics, and metabolomics, our understanding on the microbial communities, succession of LAB species, highly expressed genes, and important metabolites at different stages of kimchi fermentation has been improved greatly. All these data are useful not only for understanding the abilities of kimchi LAB to adjust to kimchi fermentation environments but also for finding methods to produce kimchi with improved functionalities. New technologies will also help scientists to find better ways to utilize LAB as probiotics and hosts for producing useful metabolites for industrial applications [9]. Compared to LAB from dairy environments, relatively few studies have been carried out for LAB originated from plant environments including kimchi. Considering the diversity of plant materials used for food fermentation and LAB inhabiting on them, extensive studies are necessary on LAB from plants, which include isolation of novel species from diverse ethnic foods, identification of metabolites, and studies on the biochemical and functional properties of metabolites $[9,10]$. Since LAB have been used for fermented foods for thousands of years, LAB and their metabolites with GRAS (generally recognized as safe) status have good potential as probiotics and starters. Recently, LAB have received much interest as hosts for producing industrially valuable commodities from renewable feedstocks due to the advantages of LAB and progress in metabolic engineering [11]. In this review, selected metabolites produced by LAB originated from kimchi are discussed for their properties, roles during kimchi fermentation, and their potential and importance for food, feed, and pharmaceutical industries.

\section{Important Metabolites Produced by Kimchi LAB}

\subsection{Bacteriocins}

Bacteriocins are proteins or peptides synthesized at ribosomes as a primary metabolite, which possess antimicrobial activities against closely related species (narrow spectrum) or diverse microorganisms (broad spectrum) [12,13]. Many LAB species secrete bacteriocins, and nisin, produced by some Lactococcus lactis strains, is the most well-known and the only commercially produced bacteriocin with approvals from governmental agencies as a food 
preservative [14]. Although research on bacteriocins has continued for several decades, industrial applications of bacteriocins are still very limited. This is largely due to the lack of stability of bacteriocins for extended periods, higher production costs, and narrow inhibition spectra in repressing spoilage or pathogenic microorganisms when applied to food systems [14]. Despite these shortcomings, bacteriocins, especially from LAB, gain continuous interests due to their potentials as safe food preservatives or alternatives for medically important antibiotics for treating infectious diseases [15]. Bacteriocins from LAB are GRAS compounds and can be incorporated into foods as purified compounds or partially purified forms. Alternatively, culture supernatant can be added, or a producing strain can be used as a starter. Since consumers prefer foods with no or fewer chemical preservatives, bacteriocins will remain as an important topic for food industry. Recent progress in protein engineering will accelerate the efforts to improve bacteriocins into better forms in terms of stability and inhibition spectra. A bacteriocin producing LAB has a good potential as a starter for kimchi fermentation. Selected LAB strains isolated from kimchi and producing bacteriocin are shown in Table 1 (references [16-30]). Most bacteriocins in Table 1 are small-sized peptides, $7 \mathrm{kDa}$ or less, except a bacteriocin from P. pentosaceus T1, which is $23 \mathrm{kDa}$ in size [30]. Many of them retained full activity after $15 \mathrm{~min}$ treatment at $121^{\circ} \mathrm{C}$, indicating their significant heat tolerance and suitability as food preservatives. Considering the small size and significant heat resistance, many bacteriocins produced by kimchi LAB are either class 1 or class 2 bacteriocins [12].

Table 1. Properties of selected bacteriocins produced by LAB isolated from kimchi.

\begin{tabular}{|c|c|c|c|c|}
\hline Strain & pH Stability & Temperature $\left({ }^{\circ} \mathrm{C}\right)$ Stability & Molecular Size (kDa) & Reference \\
\hline Lactiplantibacillus paraplantarum C7 & 2 to $8^{a}, 9^{b}, 10^{c}$ & $\begin{array}{l}100^{\circ} \mathrm{C}, 20 \mathrm{~min}, 121^{\circ} \mathrm{C}, 10 \min ^{\mathrm{b}}, \\
100^{\circ} \mathrm{C}, 30 \mathrm{~min}, 121^{\circ} \mathrm{C}, 30 \min ^{\mathrm{c}}\end{array}$ & 3.8 & [16] \\
\hline Lactiplantibacillus plantarum J9 & 3 to $10^{a}$ & $100^{\circ} \mathrm{C}, 60 \mathrm{~min}, 121^{\circ} \mathrm{C}, 15 \mathrm{~min}^{\mathrm{a}}$ & less than 6.5 & [17] \\
\hline Lactococcus lactis BH5 & 2 to $9^{\text {a }}$ & $90^{\circ} \mathrm{C}, 30 \mathrm{~min}^{\mathrm{a}}, 100^{\circ} \mathrm{C}, 30 \mathrm{~min}^{\mathrm{d}}$ & 3.7 & [18] \\
\hline Lactococcus lactis ET45 & 3 to $5^{\text {a }} 7$ to $11^{\mathrm{c}}$ & $121^{\circ} \mathrm{C}, 60 \min ^{\mathrm{a}}$ & 4.5 & [19] \\
\hline Lactococcus lactis KU24 & 3 to $7^{a}, 8$ to $9^{c}$ & $100^{\circ} \mathrm{C}, 30 \min ^{\mathrm{a}}, 121^{\circ} \mathrm{C}, 15 \min ^{\mathrm{c}}$ & 6.5 & [20] \\
\hline Lactococcus lactis LAB3113 & 2 to $10^{a}$ & $100^{\circ} \mathrm{C}, 30 \mathrm{~min}, 121^{\circ} \mathrm{C}, 20 \mathrm{~min}{ }^{\mathrm{d}}$ & 10.5 & [21] \\
\hline Lactococcus lactis subsp. lactis H-559 & 2 to $11^{\mathrm{e}}$ & $\begin{array}{l}100^{\circ} \mathrm{C}, 10 \min ^{\mathrm{a}}, 100^{\circ} \mathrm{C}, 30 \mathrm{~min}, \\
121^{\circ} \mathrm{C}, 10 \min ^{\mathrm{c}}, 121^{\circ} \mathrm{C}, 20 \min ^{\mathrm{d}}\end{array}$ & 3.3 & [22] \\
\hline Lactococcus lactis subsp. lactis J105 & $3^{\mathrm{a}}, 2,4^{\mathrm{b}}, 5^{\mathrm{c}}, 6$ to $9^{\mathrm{d}}$ & $\begin{array}{l}4^{\circ} \mathrm{C}, 24 \mathrm{~h}, 100^{\circ} \mathrm{C}, 1 \mathrm{~h}, 110^{\circ} \mathrm{C}, \\
10 \mathrm{~min}, 121^{\circ} \mathrm{C}, 15 \mathrm{~min} \mathrm{e}^{-}\end{array}$ & 3.4 & [23] \\
\hline Latilactobacillus curvatus SE1 & 2 to $11^{\mathrm{e}}$ & $100{ }^{\circ} \mathrm{C}, 60 \mathrm{~min}^{\mathrm{e}}$ & 14 & [24] \\
\hline Latilactobacillus sakei B16 & 2 to $9^{e}$ & $100{ }^{\circ} \mathrm{C}, 30 \min , 121^{\circ} \mathrm{C}, 15 \min ^{\mathrm{e}}$ & ND * & [25] \\
\hline Leuconostoc citreum $\mathrm{C} 2$ & 3 to $4^{\mathrm{a}}, 5$ to $7^{\mathrm{d}}$ & $50^{\circ} \mathrm{C}, 24 \mathrm{~h}^{\mathrm{a}}, 70^{\circ} \mathrm{C}, 24 \mathrm{~h}^{\mathrm{d}}$ & ND & [26] \\
\hline Leuconostoc citreum GJ7 & 2.5 to $9.5^{\mathrm{a}}$ & $\begin{array}{c}70^{\circ} \mathrm{C}, 24 \mathrm{~h}, 100{ }^{\circ} \mathrm{C}, 30 \mathrm{~min}, \\
121^{\circ} \mathrm{C}, 15 \mathrm{~min}^{\mathrm{a}}\end{array}$ & 3.5 & [27] \\
\hline Leuconostoc citreum GR1 & 3 to $4^{\mathrm{a}}, 5$ to $7^{\mathrm{d}}$ & $\begin{array}{c}70^{\circ} \mathrm{C}, 24 \mathrm{~h}, 100^{\circ} \mathrm{C}, 30 \mathrm{~min}, \\
121^{\circ} \mathrm{C}, 15 \mathrm{~min}^{\mathrm{a}}\end{array}$ & ND & [26] \\
\hline Leuconostoc lactis SD501 & 2 to $10^{\mathrm{e}}$ & $121^{\circ} \mathrm{C}, 15 \min ^{\mathrm{e}}$ & 7 & [28] \\
\hline Pediococcus pentosaceus K23-2 & 2 to $7^{a}, 8^{c}$ & $95^{\circ} \mathrm{C}, 30 \mathrm{~min}, 121^{\circ} \mathrm{C}, 15 \mathrm{~min}^{\mathrm{a}}$ & 5 & [29] \\
\hline Pediococcus pentosaceus $\mathrm{T} 1$ & 4 to $8^{\mathrm{e}}$ & $110^{\circ} \mathrm{C}, 20 \mathrm{~min}^{\mathrm{e}}$ & 23 & [30] \\
\hline
\end{tabular}

a $100 \%$ activity remained after treatment. ${ }^{b} 75 \%$ or more activity. ${ }^{c} 50 \%$ or more activity. ${ }^{d}$ less than $50 \%$ activity. ${ }^{e}$ activity remained but not shown numerically. ${ }^{*} \mathrm{ND}$, not determined.

Leuconostoc mesenteroides GJ7, a kimchi isolate, produced a bacteriocin whose activity was increased by the presence of sensitive cells [1]. Kimchi fermented with L. mesenteroides GJ7 showed desirable properties such as extended shelf-life and improved texture and sensory properties compared to control kimchi (no starter). It is noteworthy that L. mesenteroides remained the most dominant species, occupying $70-90 \%$ of total viable bacteria during 125 days of storage. The addition of starter to kimchi does not necessarily guarantee that the starter remains the dominant organism throughout the fermentation because the starter organism is often outcompeted by other organisms naturally present in kimchi [31]. In this respect, a bacteriocin producer has an advantage as a starter. Yeasts are regarded undesirable for kimchi fermentation since they are responsible for bad odors and a softened texture observed at later stage of fermentation. Yeasts were not detected in starter kimchi during the entire 125 days, whereas yeasts appeared after 50 days in control kimchi [1]. Leuconostoc 
citreum GR1, another kimchi isolate, produced a bacteriocin, and its bacteriocin activity was increased by the presence of some Lactobacillus species [26]. In kimchi fermented with L. citreum GR1, L. citreum GR1 impressively dominated throughout the initial fermentation period $\left(6^{\circ} \mathrm{C}, 9-12\right.$ days) and the following 2 months of storage at $-1{ }^{\circ} \mathrm{C}$. Kimchi fermented with L. citreum GR1 showed better sensory properties and higher mannitol content than control kimchi (no starter) and two other kimchi fermented with other LAB strains with antibacterial activities. Similar results were reported by Lee et al. who isolated two Leuconostoc mesenteroides strains from kimchi and used them as starters independently [32]. Kimchi fermented with each L. mesenteroides strain showed higher mannitol contents than control kimchi (no starter), and the proportions of Leuconostoc among total LAB were maintained higher, $70 \%$ at 3 weeks [32]. Interestingly, these L. mesenteroides strains were selected based on properties such as mannitol production, low acid/gas production, and acid resistance, but bacteriocin production was not considered. Considering the significant dominance $(70 \%)$ of $L$. mesenteroides, bacteriocin or other antibacterial substances might be produced in these L. mesenteroides strains. These results indicate that production of kimchi with extended shelf-life, improved taste, and enhanced functionality such as mannitol production is possible by using a starter, producing a bacteriocin and a metabolite of interest at the same time. Consumption of such kimchi might positively affect the microbiome in intestines since bacteriocins and the producing cells could inhibit sensitive pathogens in the human intestines [33]. An example is Thuricin CD, a narrow spectrum bacteriocin from Bacillus thuringiensis, which kills Clostridium difficile [34]. The addition of purified Thuricin $\mathrm{CD}$ into the fecal microbiota in a colon distal model reduced C. difficile effectively without significant impact on the composition of the microbiota. Similar effects can be expected for narrow spectrum bacteriocins from LAB. In addition to antimicrobial activity, bacteriocins may exert other health-promoting effects, such as anti-cancer and immunomodulation. Nisin administered through the oral route showed immunomodulatory effects in a mouse model and human cell line test [15], which showed a possibility that bacteriocins from LAB might exert immunomodulatory activities by affecting production of cytokines [35]. Nisin inhibited the progression of oral squamous cell carcinoma (OSCC), a subset of head and neck squamous cell carcinoma, by interfering the cross-talk between the integrin/FAK and TLR/MyD88 signaling pathway, which accelerates the progression of OSCC [36].

Considering these reports, bacteriocins from kimchi LAB including nisin can be used not only as safe and natural food preservatives but also as therapeutic agents for treating pathogen infections, some types of cancers, or improving general health by modulating immune responses or microbiota in the intestines. Recent progress in protein engineering will accelerate the development of modified bacteriocins with improved properties, and this will lead to new applications of bacteriocins for medical fields. Various nisin derivatives were obtained by replacing amino acids with different amino acids at several positions, and some mutants showed increased inhibitory activities and/or extended inhibition spectra. For example, a nisin A derivative where the 20th amino acid was changed from asparagine into proline (N20P) showed enhanced activity against Staphylococcus aureus including a MRSA isolate, and another derivative (M21V) showed higher anti-listerial activity compared to wild-type nisin A [37]. Changes at the 12th lysine or 29th serine residues such as K12A, S29G, or S29A caused the mutants to have broader inhibition spectra against Gram-positive bacteria. Attempts are being made to obtain nisin derivatives with increased stability against proteases or at alkaline pHs [37]. Bacteriocin-producing LAB isolated from kimchi are good candidates as starters for fermented foods and hosts for producing bacteriocins, which can be used for food, feed, and pharmaceutical industries. To accelerate the industrial application of bacteriocins, efforts to isolate LAB producing novel bacteriocins from diverse natural environments including plants and fermented foods should be continued. Data mining of genome sequences effectively complements the traditional screening method for bacteriocin producers. For example, 59 genomes containing putative bacteriocin-encoding gene clusters were identified through data mining of total 382 microbial genomes obtained from a human microbiome project [33]. The actual pro- 
duction of bacteriocins from the organisms should be confirmed with culture supernatant by traditional screening methods such as spot-on-the-lawn or agar well diffusion method.

\section{2. $G A B A$ ( $\gamma$-Aminobutyric Acid)}

GABA is a non-protein amino acid, and a major inhibitory neurotransmitter in the mammalian central nervous system [38]. GABA has been known to exert important physiological functions, including anti-depression, relieving anxiety, anti-hypertension, anti-diabetic effects, renal protection, etc. [39,40]. GABA is commercially available, and in Korea, products containing GABA converted from L-glutamic acid are sold as health functional foods, certified by the Korean government, with blood pressure lowering effects (https:/ / www.foodsafetykorea.go.kr/portal/healthyfoodlife/functionalityView09. do?menu_grp=MENU_NEW01\&menu_no=2657, accessed on 8 September 2021). Among microorganisms, LAB are the major GABA producers, and Lactobacillus brevis (now, Levilactobacillus brevis), often isolated from fermented foods, is the most important species. GABA is produced by irreversible decarboxylation of L-glutamate under anaerobic condition, and glutamate decarboxylase (GAD, EC 4.1.1.15) catalyzes the conversion at an acidic $\mathrm{pH}$ (Figure 1). The optimum $\mathrm{pH}$ of GAD is between 4.0 and 5.5, and pyridoxal 5-phosphate is required as a cofactor $[38,41]$. GABA production in LAB is a part of acid stress responses, and cells try to maintain intracellular $\mathrm{pH}$ at near neutral by removing internal protons through conversion of L-glutamate into GABA [41,42]. For this reason, many GABA-producing LAB species have been isolated from kimchi. The $\mathrm{pH}$ of fresh kimchi, immediately after preparation and not fermented yet, is between 5 and 6, but $\mathrm{pH}$ drops rapidly below 5 as fermentation proceeds, and the $\mathrm{pH}$ is in the range of $4.2-4.4$ at its optimum stage for consumption [43].

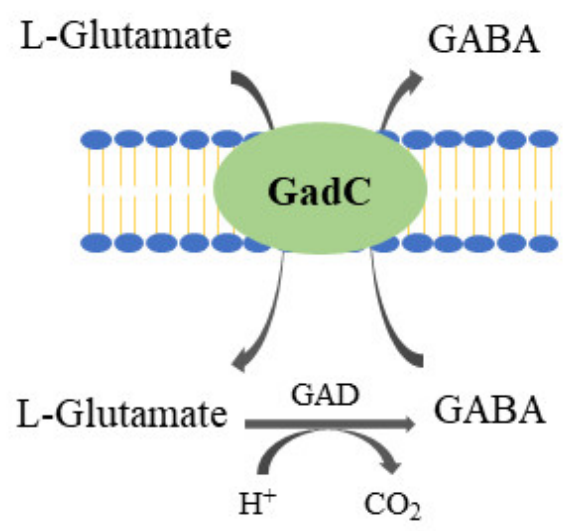

Figure 1. Schematic representation of GABA production via decarboxylation of L-glutamate catalyzed by glutamate decarboxylase. GAD, glutamate decarboxylase; GadC, glutamate/GABA antiporter.

GABA content of kimchi fermented naturally, i.e., fermented without added starter, is not high enough to confer the claimed health benefits to consumers. To increase the GABA content of kimchi, use of a starter with a high GABA-producing ability is essential because the addition of chemically synthesized GABA is not preferred by consumers. In addition to the use of a starter, kimchi fermentation should be carried out under carefully controlled conditions where the starter produces the maximum amount of GABA. In this respect, studies are necessary on the isolation of novel LAB strains with high GABA production yields, optimum fermentation conditions for the isolated strains, and methods for providing a precursor of GABA (L-glutamate or monosodium glutamate (MSG)) in sufficient amounts. A selected list of GABA-producing LAB isolated from kimchi or jeotgal is shown in Table 2 (references [44-59]). Jeotgals are Korean traditional salted and fermented sea foods prepared from small fishes, fish intestines, fish eggs, shrimps, or shellfishes. Jeotgal is often added to kimchi to enhance the flavor and the taste of kimchi [60]. Kimchi fermented with jeotgal showed higher GABA, acetate, lactate and mannitol contents than kimchi without jeotgal [60]. Jeotgals inhabiting LAB are most likely to grow in kimchi 
and play some roles during kimchi fermentation. It is noteworthy that GABA yields in Table 2 were measured differently among researchers. For example, different growth media for LAB were used, and different concentrations of GABA precursor (MSG or L-glutamate) were used under different conditions. Measurement of GABA content was performed by either the HPLC method or GABase method. Thus, it is difficult to compare GABA yields directly among the LAB strains, and readers are advised to consider this. Lactobacillus zymae (now, Levilactobacillus zymae) GU240 was isolated from kimchi and the strain produced GABA profusely [59]. Baechu kimchi was prepared by inoculating Lb. zymae GU240 as the starter $\left(10^{7} \mathrm{CFU} / \mathrm{g}\right.$ kimchi), and L-glutamic acid, MSG, or kelp extract was added separately to kimchi as a precursor of GABA [61]. Kimchi samples were fermented for 20 weeks at $-1{ }^{\circ} \mathrm{C}$. Kimchi fermented with $L b$. zymae GU240 without a precursor did not show an increase in GABA and its GABA content was not different from that of control kimchi (no starter and no precursor) at 20 weeks. Kimchi fermented with the starter and MSG $(1 \%, w / w)$ showed the highest GABA content followed by kimchi fermented with starter and kelp extract $(3 \%, w / w)$. L-glutamic acid was the least effective precursor, and its addition $(1 \%, w / w)$ inhibited the growth of starter due to its strong acidity. Although GABA content of kimchi fermented with the starter and MSG increased compared to that of control kimchi, the increase was not great, $194 \%$ of control kimchi. GABA content of kimchi (starter + MSG) was at the highest $(120.3 \mathrm{mg} / 100 \mathrm{~g}$ kimchi) at 8 weeks, and that of control kimchi was also at the highest $(62.0 \mathrm{mg} / 100 \mathrm{~g}$ kimchi) at 8 weeks. Other kimchi samples showed the highest GABA contents at 10 weeks, and those of kimchi (starter + kelp extract), kimchi (starter + L-glutamate), and kimchi (starter only) were $82.2 \mathrm{mg} / 100 \mathrm{~g}$ kimchi, $76.6 \mathrm{mg} / 100 \mathrm{~g}$ kimchi, and $69.3 \mathrm{mg} / 100 \mathrm{~g}$ kimchi, respectively. Kimchi fermented with the starter and MSG achieved the highest scores in sensory evaluation. In another study, a GABA producing Lactobacillus buchneri (now, Lentilactobacillus buchneri) was inoculated to baechu kimchi $\left(10^{5}-10^{7} \mathrm{CFU} / \mathrm{g}\right)$, and mukeunjee kimchi (overacidified kimchi) was prepared by fermentation for 3 days at $30^{\circ} \mathrm{C}$ [50]. GABA content was measured after fermentation and compared with that of control kimchi (no starter). The GABA content of mukeunjee kimchi fermented with the starter was $61.7 \pm 9.0 \mathrm{mg} / 100 \mathrm{~g}$, whereas that of mukeunjee kimchi without the starter (control) was $8.1 \pm 0.5 \mathrm{mg} / 100 \mathrm{~g}$ [50]. In this work, a precursor was not added, and this seemed to be the reason for the low yield of GABA.

Table 2. GABA production yields by LAB isolated from kimchi or jeotgal.

\begin{tabular}{|c|c|c|c|}
\hline Strain (Microorganisms) & GABA Content & MSG Concentration & Reference \\
\hline Enterococcus avium $\mathrm{M}^{\mathrm{a}}$ & $18.47 \mathrm{mg} / \mathrm{mL}$ & MRS + 3\% MSG & [44] \\
\hline Enterococcus faecium JK29 & $14.86 \mathrm{mM}$ & MRS $+0.5 \%$ MSG & [45] \\
\hline Lactiplantibacillus plantarum K154 & $201.78 \mu \mathrm{g} / \mathrm{mL}$ & MRS + 3\% MSG & [46] \\
\hline Lactococcus lactis subsp. lactis B & $3.68 \mathrm{~g} / \mathrm{L}$ & MRS + 1\% MSG & [47] \\
\hline Latilactobacillus sakei A156 a & $15.81 \mathrm{mg} / \mathrm{mL}$ & $\mathrm{MRS}+3 \% \mathrm{MSG}$ & [48] \\
\hline Latilactobacillus sakei OPK 2-59 & $58.88 \mathrm{mM}$ & MRS + 1\% MSG & [49] \\
\hline Lentilactobacillus buchneri & $5.83 \mathrm{mg} / \mathrm{mL}$ & MRS + $50 \mathrm{mM}$ glutamate & [50] \\
\hline Lentilactobacillus buchneri MS & $251 \mathrm{mM}$ & MRS $+5 \%$ MSG & [51] \\
\hline Levilactobacillus brevis $340 \mathrm{G}$ & $68.77 \mathrm{mM}$ & MRS $+3 \%$ MSG & [52] \\
\hline Levilactobacillus brevis 877G & $18.51 \mathrm{mmol} / \mathrm{L}$ & $\mathrm{MRS}+1 \% \mathrm{MSG}$ & [53] \\
\hline Levilactobacillus brevis G144 ${ }^{\text {a }}$ & $14.58 \mathrm{mM}$ & MRS + 3\% MSG & [54] \\
\hline Levilactobacillus brevis HYE1 & $18.76 \mathrm{mM}$ & MRS + 2.38\% MSG & [55] \\
\hline Levilactobacillus brevis K203 & $44.4 \mathrm{~g} / \mathrm{L}$ & MRS $+6 \%$ L-glutamate & [56] \\
\hline Levilactobacillus brevis NPS-QW-145 & $25.83 \mathrm{~g} / \mathrm{L}$ & MRS $+7 \%$ MSG & [57] \\
\hline Levilactobacillus brevis NPS-QW-267 & $24.99 \mathrm{~g} / \mathrm{L}$ & MRS + 7\% MSG & {$[57]$} \\
\hline Levilactobacillus brevis $\mathrm{T} 118^{\text {a }}$ & $\mathrm{ND}^{\mathrm{b}}$ & $\mathrm{MRS}+3 \% \mathrm{MSG}$ & [58] \\
\hline Levilactobacillus zymae GU240 & $16.94 \mathrm{mg} / \mathrm{mL}$ & MRS + 3\% MSG & {$[48,59]$} \\
\hline
\end{tabular}

${ }^{a}$ strain isolated from jeotgal. ${ }^{\mathrm{b}} \mathrm{ND}$, not determined. 
More research is necessary to increase GABA content of kimchi to meaningful levels, and these should include methods for providing a GABA precursor economically and without adverse effects on the sensory properties of kimchi, and selection of GABA producers which grow rapidly and become dominant over other LAB species naturally present among raw materials of kimchi. Additionally, a standardized procedure for measuring the GABA content of kimchi needs to be established, including collection time and collection method of kimchi samples, and the GABA assay method. One question which remains to be answered is how to alleviate the dependence of GAD on pyridoxal 5-phosphate for the activity. The addition of pyridoxal 5-phospate is not practical considering its cost. The isolation of LAB strains whose GADs do not require pyridoxal 5-phosphate or the construction of mutant GADs which no longer require pyridoxal 5-phosphate might be the answer. Detailed understanding on the GAD structure and the roles of amino acids involved in binding with a substrate or cofactor is critical for the construction of such mutants and mutants with increased GAD activities or improved stabilities [41].

In many GABA-producing LAB isolated from kimchi or jeotgal, gadB-encoding GAD forms an operon with gadC-encoding L-glutamate/GABA antiporter which is responsible for the uptake of L-glutamate into the cytoplasm and the simultaneous exclusion of GABA. The gene order $(\mathrm{gad} C B)$ was confirmed experimentally for some isolates $[44,48,54,58,59]$. Properties of purified GADs from LAB isolated from kimchi or jeotgal are shown in Table 3 (references [44-62]). Unlike gadB, little research has been performed with gadC. gadR encodes a positive transcription regulator for GABA production and is usually located upstream of the gadCB operon. Lb. brevis (now, Levilactobacillus brevis) D17 was isolated from Chinese acidic liquor product, and the strain showed enhanced gadR expression and also enhanced acid resistance [63]. Lb. brevis D17 produced much more GABA than Lb. brevis ATCC 367 when both strains were grown under the $\mathrm{pH}$-controlled and mixedfeed conditions. A gadR deletion mutant was obtained from Lb. brevis ATCC 367 and $g a d B$ and $g a d C$ were not expressed in the mutant in the presence of MSG. However, both genes together with $g a d R$ were expressed at higher levels in Lb. brevis ATCC 367 under the same conditions [63]. The results confirmed that GadR plays an important role in GABA production and show a possibility of increasing GABA production by modulating gadR expression. Further research is necessary on the detailed roles of gadC and $g a d R$ for GABA production, which will help to better understand GABA production in LAB.

Table 3. Properties of purified GADs from LAB isolated from kimchi or jeotgal.

\begin{tabular}{|c|c|c|c|c|c|c|c|c|}
\hline Strain & $\begin{array}{c}\text { MSG } \\
\text { Concentration }\end{array}$ & $\begin{array}{l}\text { Operon } \\
\text { Structure }\end{array}$ & $\begin{array}{l}\text { GAD Size } \\
\text { (aa) }\end{array}$ & $\begin{array}{c}\text { Optimal } \\
\mathrm{pH}\end{array}$ & $\begin{array}{c}\text { Optimal } \\
\text { Temp. }\left({ }^{\circ} \mathrm{C}\right)\end{array}$ & $\mathrm{K}_{\mathrm{m}}(\mathrm{mM})$ & $\mathbf{V}_{\max }$ & Reference \\
\hline $\begin{array}{l}\text { Enterococcus } \\
\text { avium } \mathrm{M} 5^{\mathrm{a}}\end{array}$ & MRS + 3\% MSG & $\operatorname{gad} C B$ & 466 & 4.5 & 55 & 3.26 & $0.012 \mathrm{mM} / \mathrm{min}$ & [44] \\
\hline $\begin{array}{c}\text { Latilactobacillus } \\
\text { sakei A156 }\end{array}$ & MRS + 3\% MSG & $\operatorname{gadCB}$ & 479 & 5.0 & 55 & 16.0 & $0.011 \mathrm{mM} / \mathrm{min}$ & [48] \\
\hline $\begin{array}{l}\text { Latilactobacillus } \\
\text { sakei OPK 2-59 }\end{array}$ & MRS + 1\% MSG & $\mathrm{ND}^{\mathrm{b}}$ & ND & $5.0^{\mathrm{c}}$ & $30^{c}$ & ND & ND & [49] \\
\hline $\begin{array}{c}\text { Levilactobacillus } \\
\text { brevis } 877 \mathrm{G}\end{array}$ & MRS + 1\% MSG & ND & 468 & 5.2 & 45 & 3.6 & $0.06 \mathrm{mM} / \mathrm{min}$ & [53] \\
\hline $\begin{array}{c}\text { Levilactobacillus } \\
\text { brevis CGMCC } 1306\end{array}$ & $0.17 \% \mathrm{MSG}^{\mathrm{c}}$ & ND & 468 & 4.8 & 48 & 10.26 & $8.86 \mathrm{U} / \mathrm{mg}$ & [62] \\
\hline $\begin{array}{c}\text { Levilactobacillus } \\
\text { brevis G144 }^{\mathrm{a}}\end{array}$ & MRS + 3\% MSG & $\operatorname{gadCB}$ & 479 & 5.0 & 40 & 8.6 & $0.01 \mathrm{mM} / \mathrm{min}$ & [54] \\
\hline $\begin{array}{l}\text { Levilactobacillus } \\
\text { zymae GU240 }\end{array}$ & $\mathrm{MRS}+3 \% \mathrm{MSG}$ & $\operatorname{gadCB}$ & 479 & 4.5 & 41 & 1.7 & $0.01 \mathrm{mM} / \mathrm{min}$ & [59] \\
\hline
\end{tabular}

${ }^{a}$ strain isolated from jeotgal. ${ }^{b} \mathrm{ND}$, not determined. ${ }^{c}$ crude cell extract was used.

\subsection{Ornithine}

Ornithine is a non-proteinogenic amino acid and a central intermediate in the urea cycle. Ornithine is derived from arginine, an essential amino acid for man and animals. Ornithine has several important physiological functions such as anti-obesity, stimulation of growth hormone, promoting muscle growth, anti-fatigue, treating cirrhosis, etc. and 
is currently available as a neutraceutical supplement, popular with athletes [64]. It was suggested that lactobacilli in the gut might contribute to the homeostasis of the gut mucus layer by producing L-ornithine from L-arginine, which in turn stimulates tryptophane metabolism in gut epithelial cells, and an increase in gut immune cells [65]. Ornithine is derived from arginine by arginine deiminase (ADI) pathway enzymes in LAB [64]. The conversion of arginine to ornithine is a part of acid stress responses in addition to serving as a source of energy, carbon, and/or nitrogen for some LAB, such as Levilactobacillus brevis [66]. Arginine enters into the cell by arginine/ornithine antiporter ( $\mathrm{ArcD}$, $\operatorname{arcD}$ gene product) with the concomitant excretion of ornithine from the cytoplasm (Figure 2). Inside the cell, arginine is converted into citrulline and ammonia by arginine deiminase (ArcA, $\operatorname{arc} A$ gene product). Citrulline is converted into ornithine and carbamoyl phosphate in the presence of a phosphate by ornithine transcarbamylase (OTC, $\operatorname{arcB}$ gene product). Carbamoyl phosphate and ADP are converted into ammonia, carbon dioxide, and ATP by carbamate kinase (CK, $\operatorname{arc} C$ gene product), and ATP is generated during this step, which helps the host cell to grow under anaerobic and acidic conditions [66]. Not all LAB carry all these arc genes, and some LAB carry just 1 or 2 genes. For example, Lactobacillus curvatus (now, Latilactobacillus curvatus) carries arcD only and Leuconostoc kimchi carries just $\operatorname{arcB}$ [64]. This explains the observation that the addition of arginine into culture encouraged the growth of some species but not others. A different type of arginine/ornithine antiporter, ArcE (arcE gene product), was found in Streptococcus pneumoniae, and ArcE bound to citrulline with higher affinity than with arginine, indicating the operation of citrulline catabolism in this host [67]. These findings indicated the importance of L-arginine/L-citruilline for the growth of some LAB species such as L. brevis under acidic environments. In such LAB species, the roles of ornithine synthesis are the same with those of GABA synthesis from L-glutamate. Ornithine or GABA helps host cells to maintain the intracellular $\mathrm{pH}$ as less acidic by ammonia production or removal of intracellular protons. Acquisition of extra ATP is another advantage for hosts [68].

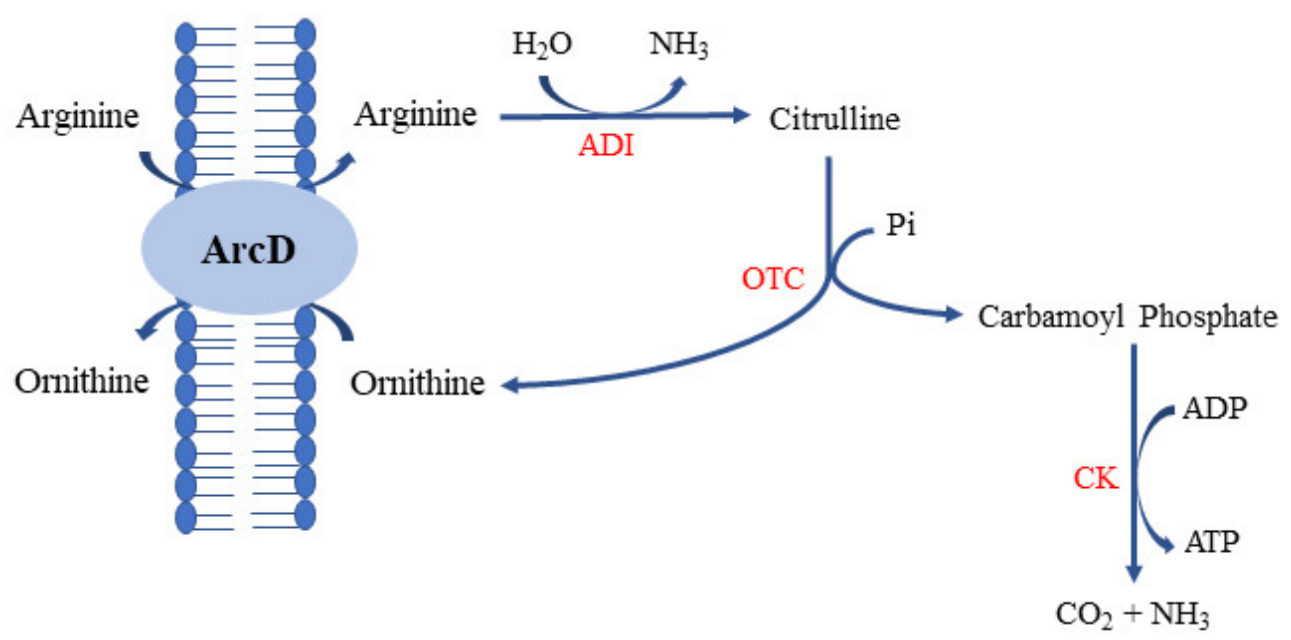

Figure 2. Schematic representation of the arginine deiminase (ADI) pathway. ADI, arginine deiminase encoded by arcA; OTC, ornithine transcarbamylase encoded by $\operatorname{arcB}$; $\mathrm{CK}$, carbamate kinase encoded by $\operatorname{arcC}$; ArcD, arginine/ornithine antiporter encoded by arcD.

Red pepper powder (RPP) is an important ingredient for kimchi, and RPP has been known to stimulate the growth of Weissella species over other LAB species during kimchi fermentation, although RPP itself does not contain Weissella species [69,70]. The addition of RPP encourages the growth of Weissella species, and Weissella species possess strong arginine deiminase activities, resulting in enhanced ornithine levels in kimchi [70]. This finding is useful for the production of kimchi enriched with ornithine. A strain with the complete ADI pathway enzymes is ideal as the starter, which includes L. brevis or Weissella species such as W. cibaria, W. confusa, or W. koreensis. Selected ornithine producing LAB isolated 
from kimchi are shown in Table 4 (references [71-74]). Kimchi fermented with W. koreensis OK1-6 showed anti-obesity effects in a mouse model where high-fat diet induced obese mice were used [75]. A group fed with a high-fat diet containing 3\% kimchi fermented with the starter showed significantly decreased lipid, insulin, and leptin concentrations together with a reduced expression of genes involved in lipid anabolism compared with control groups (high-fat diet group and high-fat diet with 3\% kimchi without starter group). In another study, mice fed with a high-fat diet and Lactobacillus brevis (now, Levilactobacillus brevis) OPK-3 ( $10^{9} \mathrm{CFU} /$ day), a kimchi isolate showing arginine deiminase activity, showed lower body weight, lower epididymal fat tissue mass, and reduced gene expressions of pro-inflammatory cytokines compared to the control (high-fat diet group) [71]. The results suggested that L. brevis OPK-3 inhibited the induction of inflammation in addition to inhibition of weight gain. Mun et al. produced a functional rice bran product enriched with ornithine and citrulline by inoculating $W$. koreensis DB1, an isolate from kimchi, into rice bran slurry $(20 \%, w / v, \mathrm{pH} 6.0)$ fortified with arginine $(3 \%, w / v)$, glucose $(2 \%, w / v)$, and corn steep liquor $(3 \%, w / v)$ [72]. After $48 \mathrm{~h}$ fermentation at $30{ }^{\circ} \mathrm{C}$, the ornithine and citrulline contents were $43,074.13 \mathrm{mg} / \mathrm{kg}$ and $27,336.37 \mathrm{mg} / \mathrm{kg}$, respectively, significantly higher than those of previous reports, and high enough to be used directly as a healthcare product without further concentration. This is a good example of converting a by-product from the food industry such as rice bran, a waste derived from rice polishing process with low commercial value, into a value-added product with an anti-obesity function. Although authors did not try to produce kimchi enriched with ornithine via the use of $W$. koreensis DB1, it seems possible to produce kimchi or other fermented foods with high ornithine contents by the same approach.

Table 4. Ornithine production yields by LAB isolated from kimchi.

\begin{tabular}{cccc}
\hline Strain & Ornithine Yield & $\begin{array}{c}\text { Arginine } \\
\text { Concentration }\end{array}$ & Reference \\
\hline Levilactobacillus brevis OPK-3 & ND & MRS $+4 \%$ arginine & {$[71]$} \\
Weissella koreensis DB1 & $43.07 \mathrm{~g} / \mathrm{kg}$ & MRS $+3 \%$ arginine & {$[72]$} \\
Weissella koreensis OK1-4 & $27.01 \mathrm{mg} / \mathrm{L} / \mathrm{h}$ & MRS $+1 \%$ arginine & {$[73]$} \\
Weissella koreensis OK1-6 & $31.41 \mathrm{mg} / \mathrm{L} / \mathrm{h}$ & MRS $+1 \%$ arginine & {$[73]$} \\
Weissella koreensis SK & $7.17 \mathrm{~g} / \mathrm{L}$ & MRS $+1 \%$ arginine & {$[74]$} \\
\hline
\end{tabular}

* ND, not determined.

\subsection{Mannitol}

Mannitol is a six-carbon sugar alcohol, and present among plants and microorganisms. In bacteria, mannitol is a compatible solute, protecting host cells against various stresses including hyperosmotic stress [76]. LAB, both homo- and heterolactic fermenters, produce mannitol but heterolactic fermenters such as Leuconostoc species produce more mannitol [77]. In heterolactic fermenters, fructose is reduced to mannitol by mannitol dehydrogenase (EC 1.1.1.67). Fructose serves not only as an electron acceptor but also as a carbon source for growth. Fructose is phosphorylated into fructose 6-phosphate (F-6-P) by fructokinase, and F-6-P is converted into glucose 6-phosphate (G-6-P). G-6-P is metabolized via the pentose phosphate pathway, converted into 1 glyceraldehyde 3-phosphate and 1 acetyl phosphate (Figure 3) [76]. A lactate is produced from glyceraldehyde 3-phosphate via the Embden-Meyerhof pathway, and either acetate or ethanol is produced from acetyl phosphate. The reduction of fructose into mannitol generates $\mathrm{NAD}^{+}$from NADH, which reduces the burden of regenerating $\mathrm{NAD}^{+}$and drives the conversion of acetyl phosphate into acetate rather than ethanol with concurrent production of 1 ATP [78]. Mannitol production yield was increased by cultivating Leuconostoc species in medium containing both glucose and fructose [76], or by the use of a mutant where fructose utilization as an energy source was blocked. Helanto et al. constructed a Leuconostoc pseudomesenteroides mutant by chemical treatment and the mutant showed $10 \%$ of wild-type fructokinase activity. The mutant produced more mannitol compared to wild type (85\% versus $74 \%, \mathrm{~mol} / \mathrm{mol}$ ) in the presence of glucose and fructose because F-6-P formation was prevented, and more fructose was con- 
verted into mannitol [79]. This is an example of obtaining strains producing more mannitol by modifying the metabolic pathway. Homolactic fermenters such as Lactococcus lactis produce mannitol from fructose 6-phosphate, which is reduced into mannitol 1-phosphate by mannitol 1-dehydrogenase (EC 1.1.1.17). Then mannitol 1-phosphate is dephosphorylated into mannitol by mannitol phosphatase [76]. LDH (L-lactate dehydrogenase)-deficient L. lactis strains were used for mannitol production and $\mathrm{NAD}^{+}$regeneration was performed by mannitol 1-dehydrogenase. The highest mannitol production was observed in an LDHdeficient $L$. lactis strain where a $m t l D$ encoding mannitol 1-dehydrogenase from Lactobacillus plantarum and a gene encoding mannitol phosphatase from Eimeria tenella were introduced and overexpressed by the NICE (nisin-controlled gene expression) system [80].

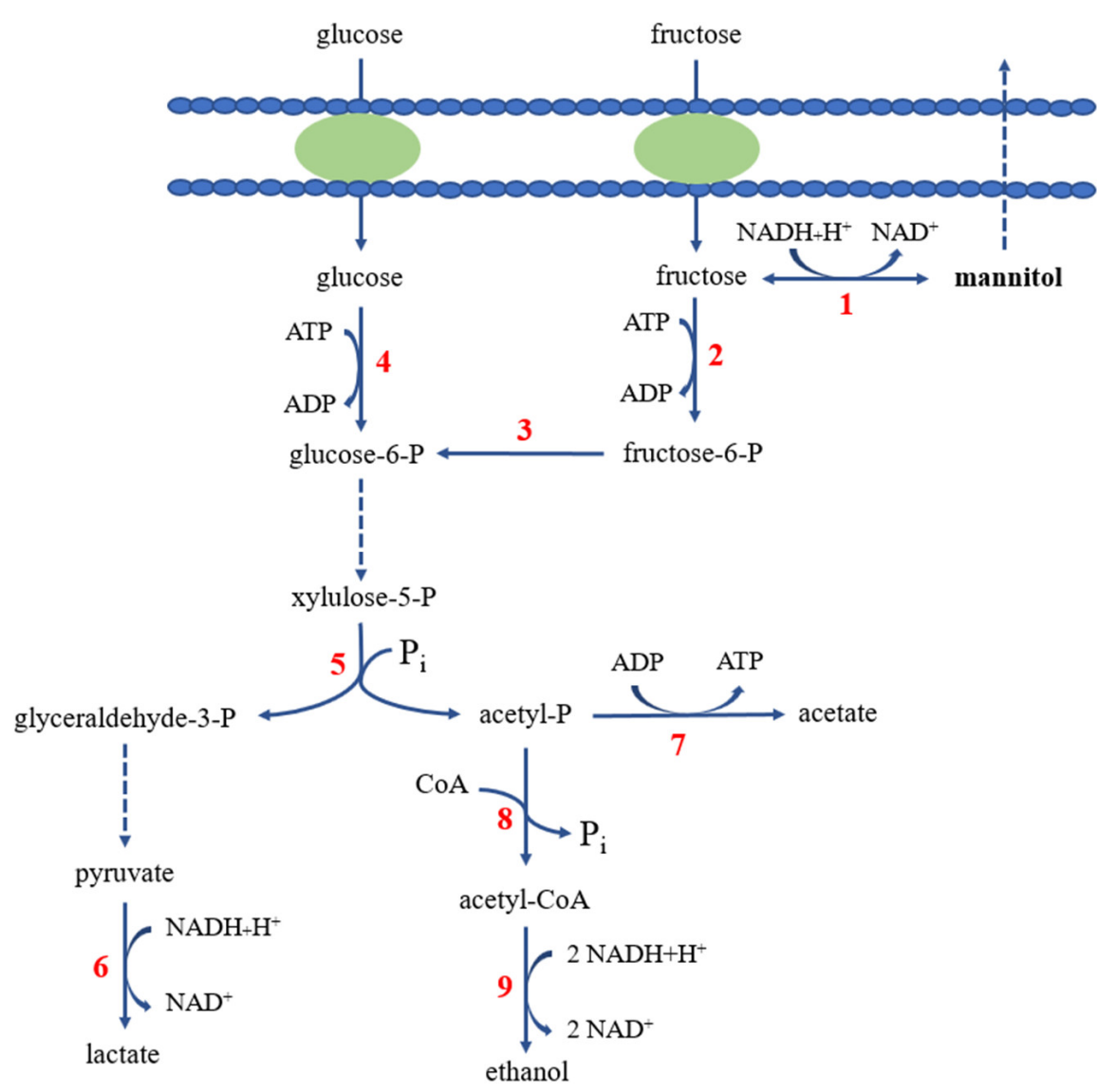

Figure 3. Mannitol production from fructose in heterolactic fermenters such as Leuconostoc species. Pathway for fructose utilization is also shown. 1, mannitol dehydrogenase; 2, fructokinase; 3 , glucose phosphate isomerase; 4 , glucokinase; 5 , phosphoketolase; 6 , lactate dehydrogenase; 7 , acetate kinase; 8, phosphate acetyltransferase; 9, acetaldehyde dehydrogenase and alcohol dehydrogenase [76]. Figure 3 was modified from Figure 2 of reference [76] with the permission from Elsevier at Sep. 9, 2021 (5144670406141).

Mannitol confers a cool, sweet taste to foods, and the sweetness is about half due to sucrose. Mannitol is not cariogenic, and does not increase blood sugar levels significantly, showing a low glycemic index, and thus being useful for diabetics [81]. Mannitol has a low caloric value $(1.6 \mathrm{kcal} / \mathrm{g})$ compared with sucrose $(4 \mathrm{kcal} / \mathrm{g})$ and is thus used as a sweetener for diet foods and chewing gum [82]. Mannitol is used in medicine as an osmotic diuretic, relieving symptoms and pains caused by edema, hydrocephalus, and glaucoma [83]. Currently, mannitol is produced by three different ways: chemical synthesis, enzymatic conversion, and microbial fermentation. Although mannitol is mostly produced by chemical methods, microbial fermentation has advantages for large-scale production because it does not require complex separation steps to remove by-products such as sorbitol, and does not require highly purified substrate, and expensive cofactor NADH [81,84]. 
Leuconostoc species are heterolactic fermenters, and the most important group during the early and middle stages of kimchi fermentation [8]. Therefore, Leuconostoc species such as L. mesenteroides isolated from kimchi seem to be ideal hosts for mannitol production by fermentation. Such strains are also useful as kimchi starters since mannitol confers a refreshing taste to kimchi, and kimchi starters producing mannitol could be valuable probiotics considering the beneficial effects of mannitol. Otgonbayar et al. compared nine Leuconostoc strains previously isolated from kimchi for mannitol production and found that L. citreum KACC 91348P grew quickly in MRS broth and produced more mannitol than others [85]. The highest mannitol production $(14.83 \mathrm{~g} / \mathrm{L} / \mathrm{h})$ was observed when L. citreum KACC $91348 \mathrm{P}$ was cultivated in a $2 \mathrm{~L}$ batch fermenter at $30{ }^{\circ} \mathrm{C}$ and a constant $\mathrm{pH}$ of 6.5. Jung et al. prepared baechu kimchi using a mannitol-producing L. mesenteroides strain as the starter $\left(10^{7}\right.$ cells $/ g$ kimchi), and the mannitol content of starter kimchi was higher than that of non-starter kimchi during 40 days of fermentation at $4{ }^{\circ} \mathrm{C}$ [86]. During fermentation, mannitol content of kimchi increased as the same pattern with total bacterial cells, whereas fructose content decreased. Kim et al. prepared baechu kimchi by inoculating mixed starters consisting of Lactococcus lactis and Leuconostoc citreum [87]. L. lactis WiKim0098 showed strong antimicrobial activity and L. citreum WiKim0096 produced more mannitol than other LAB tested. When kimchi was fermented with mixed starters, overacidification of kimchi was delayed because of growth inhibition of LAB naturally present in kimchi ingredients by L. lactis WiKim0098 compared to control kimchi. The mannitol content of starter kimchi was $5.1 \mathrm{mg} / \mathrm{mL}$, higher than that of control kimchi $(3.4 \mathrm{mg} / \mathrm{mL})$ [87]. So far, kimchi fermentation has not been reported with intentionally added fructose. If fructose is added to kimchi, more mannitol is likely to be produced, and it will be interesting to examine the properties of kimchi, such as mannitol content, growth of LAB, and sensory properties. Rice et al. reported an interesting application of a Leuconostoc strain for production of a healthy beverage [78]. A Leuconostoc citreum was isolated from sour doughs and inoculated into apple juice as a starter. Fructose and sucrose contents of apple juice were decreased significantly ( $83 \%$ reduction) with the concomitant increase in mannitol $(61.6 \mathrm{~g} / \mathrm{L})$ after $48 \mathrm{~h}$ fermentation in a $1 \mathrm{~L}$ bioreactor system. The product contained less sugars, but still maintained sweetness due to mannitol, showing a possibility of producing healthier beverages by converting fructose into mannitol.

\subsection{Exopolysaccharides}

Exopolysaccharides (EPSs) are biopolymers synthesized by microorganisms such as bacteria, fungi, and blue-green algae [88]. EPSs are located outside of cells, either attached to the cell surface tightly or loosely, or detached from the cell. EPSs have several protective roles for hosts, including protection from viruses, predators, dehydration, or toxic chemicals [89]. EPSs from LAB have been the subject of many studies because they have important effects on the rheological, organoleptic, and functional properties of foods. Currently, EPSs from LAB, considered GRAS compounds, have been used in food, pharmaceutical, cosmetic, and chemical industries. Recently, EPSs and their modified derivatives are receiving attention due to their potential as carriers for drugs [90]. EPSs are classified into two types: homopolymers (hoPO) and heteropolymers (htPO). The former consists of a single monosaccharide such as glucose or fructose, and the latter consists of at least two different monosaccharides connected at different positions [91]. The sizes and properties of EPSs are variable depending upon the host bacteria, substrates, and growth environments. Dextran is the most well-known hoPO produced by some Leuconostoc, Lactobacillus, and Streptococcus species grown on sucrose-containing medium. Dextran consists of $\alpha$-D-glucose units connected via $\alpha-1 \rightarrow 6$ glycosidic bonds with a few branches connected via $\alpha-1 \rightarrow 3$ bonds, and occasionally $\alpha-1 \rightarrow 2$ or $\alpha-1 \rightarrow 4$ linkages [88,92]. In the food industry, dextran is used for increasing the viscosity and volume of foods, moisture retention, prevention of crystallization, and improving the texture of foods [93]. In medicine, dextran is used as an antithrombotic, to reduce blood viscosity, and as a volume expander in hypovolaemia. Dextran also receives interest as a potential drug carrier due to its excellent water solubility, 
biocompatibility, biodegradability, and low toxicity. Dextran can be modified to various forms, such as nanoparticles, gel, microspheres, sponge, liposome, etc., to carry a drug and release it slowly in body [90]. EPSs from LAB show anti-cancer, anti-inflammatory, antioxidant, anti-viral, anti-biofilm, anti-diabetic, and immunomodulatory activities [94]. EPSs from $L A B$ show anti-cancer activities via various mechanisms including anti-proliferation, apoptosis induction, cell cycle arrest, mutagenicity inhibition, oxidative stress modulation, angiogenesis inhibition and inflammatory amelioration [95]. The anti-cancer effects of EPSs vary depending on the production host, chemical structures, and purity of EPS, and further research is necessary for elucidation of the exact mechanisms. Lactobacillus plantarum (now, Lactiplantibacillus plantarum) LRCC5310 was isolated from kimchi, and its EPS showed an antiviral effect against the human rotavirus Wa strain in vitro [96]. Oral administration of the EPS into mice reduced the duration of diarrhea, viral shedding, and destruction of enteric epithelium integrity in infected mice [96]. L. mesenteroides BioE-LMD18, an isolate from kimchi, produced an EPS of $123.8 \mathrm{kDa}$ in size, which showed immunomodulatory effects in RAW 264.7 murine macrophage cells previously treated with lipopolysaccharide (LPS) from Escherichia coli [97]. EPS treatment reduced the amount of IL-6, a pro-inflammatory cytokine, by $32.1 \%$, but increased the amount of IL-10, an anti-inflammatory cytokine, by a dose-dependent manner in LPS-treated cells. The EPS from L. mesenteroides BioELMD18 was a htPO, consisting of mannose $(8.71 \%)$, arabinose $(0.07 \%)$, galactose $(1.22 \%)$, fucose $(10.21 \%)$, and glucose $(79.8 \%)$. Similar immunomodulatory effects were previously reported for dextrans from four L. mesenteroides and one Lactobacillus sakei isolates [98]. When these dextrans were independently given to human monocytic leukemia cell line THP-1, the amount of pro-inflammatory TNF- $\alpha$ was reduced, whereas that of IL-10 was increased. More studies are necessary on the relationships between the structures and the biofunctionalities of EPSs from LAB. However, data so far are enough to claim that EPSs such as dextran have great potential for food and pharmaceutical industries.

LAB-producing EPSs with desirable properties are promising probiotics and also starters for fermented foods such as kimchi and fermented dairy products. For example, two Weissella cibaria strains were isolated from kimchi, and they showed desirable properties including resistance against acid and bile salts, sensitivity to antibiotics, strong adhesion to intestinal epithelial cells, inhibition of some food pathogens, high butyric acid production, and EPS production [99]. Such strains have potentials as starters for functional foods and/or probiotics, but the real efficacy of each strain should be confirmed experimentally. EPSs produced by LAB are the products of complex metabolic processes involving many genes responsible for the syntheses and modifications of sugars and their regulations. In addition to genetic elements, the availability of sugars and environments also affect the types of EPSs produced. Scientists have been trying to overproduce EPSs or produce EPSs with improved properties through metabolic engineering such as insertion of heterologous genes and/or inactivation of inherent genes, thus modifying biosynthetic pathways or creating new pathways for the optimum synthesis of an EPS [100-102]. For example, a gene encoding NADH oxidase from Streptococcus mutans was introduced into Lactobacillus casei LC2W, an EPS producer. The recombinant strain produced $46 \%$ more EPS compared to wild type [101]. The increase was due to less lactate production because the heterologous NADH oxidase oxidized NADH into $\mathrm{NAD}^{+}$, thus reducing the need of pyruvate reduction into lactate [101]. This kind of so-called "cofactor engineering" is a common strategy used for the genetic engineering of LAB strains, and the purpose is the production of an alternative product such as L-alanine, diacetyl, acetoin, mannitol, EPS, or 2,3-butanediol instead of lactate. The same strategy is useful for the overproduction of EPSs by strains isolated from kimchi. It can be envisioned that a LAB strain producing a functional EPS, a bacteriocin, GABA, mannitol, etc. simultaneously can be constructed by use of state-of-the art technologies and used for the production of foods with multifunctionalities. Alternatively, a group of strains will be constructed, and each strain is tailored for the production of a specific metabolite and used as necessary. Advances in 
metabolic engineering combined with multi-omics technologies are likely to make this scenario come true in the near future [102].

\subsection{2-Hydroxyisocaproic Acid and 3-Phenyllactic Acid}

2-Hydroxyisocaproic acid (HICA) and 3-phenyllactic acid (PLA) are metabolites produced by bacteria including $\mathrm{LAB}$, and they are receiving attention due to their antimicrobial activities and other useful properties. Both are end products from amino acids catabolism31. HICA is derived from L-leucine and PLA from L-phenylalanine [103,104]. For HICA production, leucine is first converted into 2-ketoisocaproic acid (KICA) by a branched-chain amino acid aminotransferase which transfers the amino group of leucine to $\alpha$-ketoglutarate. Then KICA is reduced into HICA by hydroxyisocaproate dehydrogenase (HicD, product of hicD) (Figure 4A) [105]. For PLA production, phenylalanine is converted into phenylpyruvic acid (PPA) by an aminotransferase, and then PPA is reduced to PLA by a dehydrogenase such as lactate dehydrogenase (Figure 4B) [106]. NADH provides the reducing power for the reaction. Recently, it was proposed that PLA might be produced not only by the catabolism of phenylalanine but also by the anabolic pathway for phenylalanine synthesis [104]. Both HICA and PLA possess antibacterial and antifungal activities, and they are considered as food preservatives or topical agents for treating bacterial and fungal infections. When beef cuts were surface sprayed with PLA (1.5\%), all inoculated E. coli O157:H7 and Salmonella Typhimurim cells were inactivated [107]. HICA is also known to increase muscle mass and help recovery after exercise, and is used as a supplement for athletes [108]. However, a contradictory report was published where administration of HICA to young adults showed no effect on muscle growth [109]. PLA has a potential to serve as a building block for poly (PLA), which has some desirable properties as a degradable bioplastic [110]. 3T3-L1 preadipocytes treated with PLA showed increases in glucose uptake and adipocyte differentiation by activation of PPAR- $\gamma 2$ [111]. From these observations, it was suggested that PLA might have a potential as a drug for preventing type-2 diabetes mellitus. Immunomodulatory effects of PLA were also suggested. The consumption of fermented foods such as sauerkraut, which contained PLA in $\mu \mathrm{M}$ concentration, caused the increase in the blood PLA level, which in turn affected monocyte functions and caused immunomodulation via the binding of PLA to hydroxycarboxylic acid receptor 3 at monocytes and immune cells of man [112].

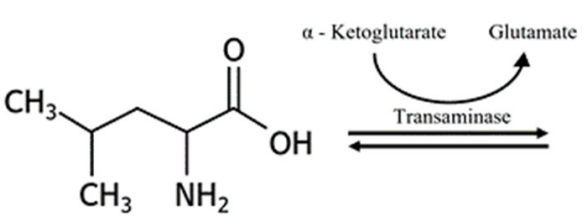

L - Leucine<smiles>CC(C)CC(=O)C(=O)O</smiles>

KICA

(A)<smiles>NC(Cc1ccccc1)C(=O)O</smiles>

L - Phenylalanine

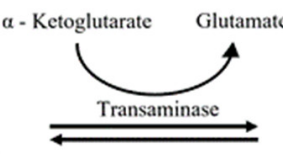<smiles>O=C(O)C(=O)Cc1ccccc1</smiles>

PPA

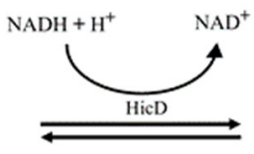<smiles>CC(C)C[C@H](O)C(=O)O</smiles>

HICA

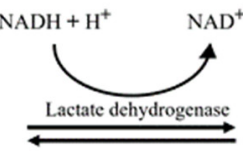<smiles>O=C(O)C(O)Cc1ccccc1</smiles>

PLA

(B)

Figure 4. Production of HICA (A) and PLA (B) from corresponding amino acid precursor, L-leucine and L-phenylalanine, respectively. KICA, 2-ketoisocaproic acid; HICA, 2-hydroxyisocaproic acid; PPA, phenylpyruvic acid; PLA, 3-phenyllactic acid. 
The amount of HICA and PLA produced are different among LAB species. When LAB species isolated from kimchi were compared for HICA production after cultivation in MRS broth, Lb. plantarum produced the largest amount of HICA followed by L. mesenteroides, but $L b$. sakei and Pediococcus pentosaceus produced small amounts [105]. The amount of HICA produced by a specific LAB species seemed to be closely related to the number of hicD gene and its expression level. It was shown that $L b$. plantarum had three or four hidD genes and L. mesenteroides had one gene on the genomes. However, no hicD gene was located on the genomes of $L b$. sakei and P. pentosaceus [113]. Putative hicD genes are located on the genomes of many LAB species, but their functions have not been confirmed experimentally in most cases. In Lb. plantarum and L. mesenteroides, hicD expressions were increased at acidic conditions, and higher expressions were observed at $\mathrm{pH} 4.5$ compared to at $\mathrm{pH} 5.5$ [105]. Since overall functionality of a fermented food is determined by the sum of all effective metabolites [11], the use of multiple starters, where each member provides a specific function, may be an effective method to improve the overall functionalities of fermented foods as long as starters are compatible with each other.

HICA effectively inhibited the growth of Enterococcus faecalis, a causative organism of dental cary [114]. HICA inhibited the growth of planktonic Candida albicans cells and also biofilm formation. The reduction in pre-grown biofilm was most effective at an acidic $\mathrm{pH}$, and the mutagenic acetaldehyde was not produced from glucose at acidic $\mathrm{pH}$ [115]. HICA extended the shelf-life of bread by inhibiting the growth of fungi in sourdough [103]. HICA and PLA clearly inhibited the growth of mold in bread, but the amount of total carboxylic acids, including HICA and PLA of a specific strain, did not match exactly with the strength of inhibition by that strain, indicating involvement of other unknown metabolites for the inhibition [103]. HICA acted as a fungicide and killed Candida and Aspergillus species at high concentration $(72 \mathrm{mg} / \mathrm{mL})$ and acted as a fungistatic at lower concentrations [116]. HICA and PLA are produced during kimchi fermentation by LAB. However, HIKA contents of five commercial kimchi stored for 2-4 weeks were low, ranging from $7.1 \pm 0.1$ to $22.6 \pm 0.4 \mu \mathrm{g} / \mathrm{mL}$ [105]. Antimicrobial activity is hardly expected at this low level of HICA. However, LAB produce other inhibitory metabolites, such as organic acids, bacteriocins, hydrogen peroxide, and small-sized inhibitory compounds such as reuterin. All these compounds work synergistically to inhibit pathogens and spoilage microorganisms. Thus, the ability of a strain to produce HICA and/or PLA is an advantage because it is likely to serve as another hurdle for pathogens. Since the production of HICA and PLA is affected by the activities of responsible enzymes such as HisD and the availability of corresponding amino acids (leucine and phenylalanine), it seems possible to increase the content of HICA and PLA of kimchi or other fermented foods to certain levels by use of starters with high enzyme activities and with precursor amino acids in sufficient amounts. The content of HICA in kimchi is affected by the dominant LAB species. The addition of L. mesenteroides or Lb. plantarum $\left(10^{7} \mathrm{CFU} / \mathrm{g}\right.$ kimchi) to kimchi increased HICA content compared to control kimchi [105]. For this reason, it was suggested that HICA content of kimchi might be used as an indicator for kimchi fermentation [105]. Similarly, the amount of PLA in kimchi or other fermented foods is likely to be closely related to the dominant LAB species.

\section{Conclusions}

Plants inhabiting LAB have great potential not only as starters for fermented foods such as kimchi, sauerkraut, and pickles but also as probiotics for humans, animals, poultries, and fishes. LAB also have good potential and receive interest as cell factories for the production of value-added products, including vitamins, 1, 3-propandiol, diacetyl, hyaluronic acid, exopolysaccharides, platform chemicals for bioplastics and biofuels, antibodies, etc. [11] LAB transform nutrients in foods into more bioactive forms or more easily absorbed forms in human intestines by enzyme activities during fermentation. Biotransformation (bioconversion) capabilities of LAB are useful for the precise production of valuable chemicals from their precursors [117]. Considering these advantages, the importance of 
$\mathrm{LAB}$, especially from plant sources which have been relatively less utilized, will increase in food and other related industries. Although important LAB species involved in kimchi fermentation have been identified, and many of their genomes have been sequenced, detailed knowledge on the functions and potentials of metabolites are still scarce, especially for their effects inside human bodies.

Kimchi serves as a model food for studying the biochemical, physiological, and genetic strategies of LAB species to adapt to acidic, low-temperature, and anaerobic kimchi environments. Metabolites such as GABA, ornithine, bacteriocins, exopolysaccharides, etc. are the products resulting from efforts of LAB to thrive and outcompete other microorganisms under kimchi environments. Therefore, it is necessary to have a deep understanding of the metabolites including the production pathways, key enzymes, regulatory mechanisms, and the roles and potentials as functional materials if a better or novel utilization of LAB is tried. Isolation of novel LAB strains with some functionalities is important for the development of products with commercial value. For example, one popular health functional product certified by the Korean government is based on Lb. plantarum CJLP133, which was obtained through screening of 3500 LAB isolates from kimchi. The administration of the strain improves conditions of sensitive skin such as atopic dermatitis, and the effect was proven scientifically [118]. Progress in bioinformatics, such as the identification of potentially useful genes through data mining of genome sequences, metabolic engineering, and genome editing techniques such as CRISPR/Cas9, will make it possible to construct novel strains designed for the optimum production of specific metabolites via food-grade manners; thus, constructed strains can be used directly for food fermentation as starters or probiotics. Similarly, strains producing bacteriocins inhibiting pathogens or eliciting immune responses in human intestines are likely to be constructed and used to improve human health. The recent surge of interest in the human microbiome will accelerate research on probiotics and the expected results contribute to finding novel methods to improve our health.

Funding: This work was funded by the Ministry of Agriculture, Food and Rural Affairs, Republic of Korea, grant number IPET918005044HD070.

Acknowledgments: This work was supported by the Strategic Initiative for Microbiomes in Agriculture and Food, Ministry of Agriculture, Food and Rural Affairs, Republic of Korea, grant number IPET918005044HD070. S.-J.L., H.-S.J. and J.-Y.Y. were supported by BK21 Four program from the Ministry of Education, Korea.

Conflicts of Interest: The authors declare no conflict of interest.

\section{References}

1. Chang, J.Y.; Chang, H.C. Improvements in the quality and shelf life of kimchi by fermentation with the induced bacteriocinproducing strain, Leuconostoc citreum GJ7 as a starter. J. Food Sci. 2010, 75, M103-M110. [CrossRef]

2. Lee, S.H.; Jung, J.Y.; Jeon, C.O. Source tracking and succession of kimchi lactic acid bacteria during fermentation. J. Food Sci. 2015, 80, M1871-M1877. [CrossRef] [PubMed]

3. Park, K.Y.; Jeong, J.K.; Lee, Y.E.; Daily, J.W., III. Health benefits of kimchi (Korean fermented vegetables) as a probiotic food. J. Med. Food 2014, 17, 6-20. [CrossRef]

4. Dimiti, E.; Cox, S.R.; Rossi, M.; Whelan, K. Fermented foods: Definition and characteristics, impact on the gut microbiota and effects on gastrointestinal health and disease. Nutrients 2019, 11, 1806. [CrossRef] [PubMed]

5. Marco, M.L.; Heeney, D.; Binda, S.; Cifelli, C.J.; Cotter, P.D.; Foligné, B.; Gänzle, M.; Hutkins, R.; Pasin, G.; Pihlanto, A.; et al. Health benefits of fermented foods: Microbiota and beyond. Curr. Opin. Biotechnol. 2017, 44, 94-102. [CrossRef]

6. Park, E.J;; Chun, J.; Cha, C.J.; Park, W.S.; Jeon, C.O.; Bae, J.W. Bacterial community analysis during fermentation of ten representative kinds of kimchi with barcoded pyrosequencing. Food Microbiol. 2012, 30, 197-204. [CrossRef] [PubMed]

7. Jung, J.Y.; Lee, S.H.; Jeon, C.O. Kimchi microflora: History, current status, and perspectives for industrial kimchi production. Appl. Microbiol. Biotechnol. 2014, 98, 2385-2393. [CrossRef] [PubMed]

8. Lee, M.E.; Jang, J.Y.; Lee, J.H.; Park, H.W.; Choi, H.J.; Kim, T.W. Starter cultures for kimchi fermentation. J. Microbiol. Biotechnol. 2015, 25, 559-568. [CrossRef]

9. Wuyts, S.; Beeck, W.V.; Allonsius, C.N.; van den Broek, M.F.L.; Lebeer, S. Applications of plant-based fermented foods and their microbes. Curr. Opin. Biotechnol. 2020, 61, 45-52. [CrossRef] 
10. Yu, A.; Leveau, J.H.J.; Marco, M.L. Abundance, diversity and plant-specific adaptations of plant-associated lactic acid bacteria. Environ. Microbiol. Rep. 2020, 12, 16-29. [CrossRef]

11. Hatti-Kaul, R.; Chen, L.; Dishisa, T.; Enshasy, H.E. Lactic acid bacteria: From starter cultures to producers of chemicals. FEMS Microbiol. Lett. 2018, 365, fny213. [CrossRef]

12. Hols, P.; Ledesma, G.L.; Gabant, P.; Mignolet, J. Mobilization of microbiota commensals and their bacteriocins for therapeutics. Trends Microbiol. 2019, 27, 690-702. [CrossRef] [PubMed]

13. Agriopoulou, S.; Stamatelopoulou, E.; Sachadyn-Król, M.; Varzakas, T. Lactic acid bacteria as antibacterial agents to extend the shelf life of fresh and minimally processed fruits and vegetables: Quality and safety aspects. Microorganisms 2020, 8, 952. [CrossRef] [PubMed]

14. O'Connor, P.M.; Kuniyoshi, T.M.; Oliveira, R.P.S.; Hill, C.; Ross, R.P.; Cotter, P.D. Antimicrobials for food and feed; a bacteriocin perspective. Curr. Opin. Biotechnol. 2020, 61, 160-167. [CrossRef]

15. Shin, J.M.; Gwak, J.W.; Kamarajan, P.; Fenno, J.C.; Rickard, A.H.; Kapila, Y.L. Biomedical applications of nisin. J. Appl. Microbiol. 2015, 120, 1449-1465. [CrossRef] [PubMed]

16. Lee, K.H.; Park, J.Y.; Jeong, S.J.; Kwon, G.H.; Lee, H.J.; Chang, H.C.; Kim, J.H. Characterization of Paraplantaricin C7, a Novel Bacteriocin Produced by Lactobacillus parapplantarum C7 Isolated from Kimchi. J. Microbiol. Biotechnol. 2007, 17, 287-296. Available online: https:/ / www.koreascience.or.kr/article/JAKO200710912611025.pdf (accessed on 8 September 2021).

17. Kim, H.T.; Park, J.Y.; Lee, G.G.; Kim, J.H. Isolation of a bacteriocin-producing Lactobacillus plantarum strain from kimchi. Food Sci. Biotechnol. 2003, 12, 166-170. [CrossRef]

18. Hur, J.W.; Hyun, H.H.; Pyun, Y.R.; Kim, T.S.; Yeo, I.H.; Paik, H.D. Identification and partial characterization of lacticin BH5, a bacteriocin produced by Lactococcus lactis BH5 isolated from Kimchi. J. Food Prot. 2000, 63, 1707-1712. [CrossRef]

19. Jeong, S.Y.; Park, C.S.; Choi, N.S.; Yang, H.J.; Kim, C.Y.; Yoon, B.D.; Kim, M.S. Characteristics of bacteriocin produced by Lactococcus lactis ET45 isolated from kimchi. Korean J. Microbiol. 2011, 47, 74-80.

20. Lee, N.K.; Jin Han, E.; Jun Han, K.; Paik, H.D. Antimicrobial effect of bacteriocin KU24 produced by Lactococcus lactis KU24 against methicillin-resistant Staphylococcus aureus: Characterization of bacteriocin KU24. J. Food Sci. 2013, 78, M465-M469. [CrossRef]

21. Shin, J.Y.; Cheol, A. Characterization of Bacteriocin Production by Lactococcus lactis LAB3113 Isolated from Kimchi. J. Food Sci. Nutr. 1997, 2, 101-108. Available online: http:/ / www.dbpia.co.kr/journal/articleDetail?nodeId=NODE00636627 (accessed on 8 September 2021).

22. Lee, H.J.; Joo, Y.J.; Park, C.S.; Kim, S.H.; Hwang, I.K.; Ahn, J.S.; Mheen, T.I. Purification and characterization of a bacteriocin produced by Lactococcus lactis subsp. lactis H-559 isolated from kimchi. J. Biosci. Bioeng. 1999, 88, 153-159. [CrossRef]

23. Kwak, G.S.; Kim, S.K.; Jun, H.K. Purification and characterization of bacteriocin J105 produced by Lactococcus latis subsp. lactis J105 isolated from kimchi. J. Microbiol. Biotechnol. 2001, 11, 275-280.

24. Kim, S.K.; Lee, E.J.; Park, K.Y.; Jun, H.K. Bacteriocin produced by Lactobacillus curvatus SE1 isolated from kimchi. J. Microbiol. Biotechnol. 1998, 8, 588-594.

25. Ahn, J.E.; Kim, J.K.; Lee, H.R.; Eom, H.J.; Han, N.S. Isolation and characterization of a bacteriocin-producing Lactobacillus sakei B16 from kimchi. J. Korean Soc. Food Sci. Nutr. 2012, 41, 721-726. [CrossRef]

26. Moon, S.H.; Kim, C.R.; Chang, H.C. Heterofermentative lactic acid bacteria as a starter culture to control kimchi fermentation. LWT-Food Sci. Technol. 2018, 88, 181-188. [CrossRef]

27. Chang, J.Y.; Lee, H.J.; Chang, H.C. Identification of the agent from Lactobacillus plantarum KFRI464 that enhances bacteriocin production by Leuconostoc citreum GJ7. J. Appl. Microbiol. 2007, 103, 2504-2515. [CrossRef]

28. Hwang, I.C.; Oh, J.K.; Kim, S.H.; Oh, S.; Kang, D.K. Isolation and characterization of an anti-listerial bacteriocin from Leuconostoc lactis SD501. Korean J. Food Sci. Anim. Resour. 2018, 38, 1008-1018. [CrossRef]

29. Shin, M.S.; Han, S.K.; Ryu, J.S.; Kim, K.S.; Lee, W.K. Isolation and partial characterization of a bacteriocin produced by Pediococcus pentosaceus K23-2 isolated from kimchi. J. Appl. Microbiol. 2008, 105, 331-339. [CrossRef]

30. Jang, S.; Lee, J.; Jung, U.; Choi, H.S.; Suh, H.J. Identification of an anti-listerial domain from Pediococcus pentosaceus T1 derived from kimchi, a traditional fermented vegetable. Food Control 2014, 43, 42-48. [CrossRef]

31. Miller, E.R.; Kearns, P.J.; Niccum, B.A.; Schwartz, J.Ó.; Ornstein, A.; Wolfe, B.E. Establishment limitation constrains the abundance of lactic acid bacteria in the Napa cabbage phyllosphere. Appl. Environ. Microbiol. 2019, 85, e00269-19. [CrossRef]

32. Lee, K.W.; Kim, G.S.; Baek, A.H.; Hwang, H.S.; Kwon, D.Y.; Kim, S.G.; Lee, S.Y. Isolation and characterization of kimchi starters Leuconostoc mesenteroides PBio03 and Leuconostoc mesenteroides PBio04 for manufacture of commercial kimchi. J. Microbiol. Biotechnol. 2020, 30, 1060-1066. [CrossRef]

33. Walsh, C.J.; Guinane, C.M.; Hill, C.; Ross, R.P.; O'Toole, P.W.; Cotter, P.D. In silico identification of bacteriocin gene clusters in the gastrointestinal tract, based on the human microbiome project's reference genome database. BMC Microbiol. $2015,15,183$. [CrossRef]

34. Rea, M.C.; Dobson, A.; O'Sullivan, O.; Crispie, F.; Fouhy, F.; Cotter, P.D.; Shanahan, F.; Kiely, B.; Hill, C.; Ross, R.P. Effect of broad and narrow-spectrum antimicrobials on clostridium difficile and microbial diversity in a model of the distal colon. Proc. Natl. Acad. Sci. USA 2011, 108, 4639-4644. [CrossRef] [PubMed]

35. Małaczewska, J.; Kaczorek-Łukowska, E. Nisin-A lantibiotic with immunomodulatory properties: A review. Peptides 2021, 137, 170479. [CrossRef] [PubMed] 
36. Kamarajan, P.; Ateia, I.; Shin, J.M.; Fenno, J.C.; Le, C.; Zhan, L.; Chang, A.; Darveau, R.; Kapila, Y.L. Periodontal pathogens promote cancer aggressivity via TLR/MyD88 triggered activation of Integrin/FAK signaling that is therapeutically reversible by a probiotic bacteriocin. PLoS Pathog. 2020, 16, 1-27. [CrossRef]

37. Field, D.; Cotter, P.D.; Ross, R.P.; Hil, C. Bioengineering of the model lantibiotic nisin. Bioengineered 2015, 6, 187-192. [CrossRef] [PubMed]

38. Cui, Y.; Miao, K.; Niyaphorn, S.; Qu, X. Production of gamma-aminobutyric acid from lactic acid bacteria: A systematic review. Int. J. Mol. Sci. 2020, 21, 995. [CrossRef]

39. Xu, N.; Wei, L.; Liu, J. Biotechnological advances and perspectives of gamma-aminobutyric acid production. World J. Microbiol. Biotechnol. 2017, 33, 64. [CrossRef]

40. Ngo, D.H.; Vo, T.S. An updated review on pharmaceutical properties of gamma-aminobutyric acid. Molecules 2019, $24,2678$. [CrossRef]

41. Yogeswara, I.B.A.; Maneerat, S.; Haltrich, D. Glutamate decarboxylase from lactic acid bacteria-A key enzyme in GABA synthesis. Microorganisms 2020, 8, 1923. [CrossRef]

42. Sarasa, S.B.; Mahendran, R.; Muthusamy, G.; Thankappan, B.; Selta, D.R.F.; Angayarkanni, J. A brief review on the non-protein amino acid, gamma-amino butyric acid (GABA): Its production and role in microbes. Curr. Microbiol. 2020, 77, 534-544. [CrossRef]

43. Kim, J.; Bang, J.; Beuchat, L.R.; Kim, H.; Ryu, J.H. Controlled fermentation of kimchi using naturally occurring antimicrobial agents. Food Microbiol. 2012, 32, 20-31. [CrossRef]

44. Lee, K.W.; Shim, J.M.; Yao, Z.; Kim, J.A.; Kim, H.J.; Kim, J.H. Characterization of a glutamate decarboxylase (GAD) from Enterococcus avium M5 isolated from jeotgal, a korean fermented seafood. J. Microbiol. Biotechnol. 2017, 27, 1216-1222. [CrossRef]

45. Lim, H.S.; Cha, I.T.; Lee, H.; Seo, M.J. Optimization of $\gamma$-aminobutyric acid production by Enterococcus faecium JK29 isolated from a traditional fermented foods. Microbiol. Biotechnol. Lett. 2016, 44, 26-33. [CrossRef]

46. Park, S.Y.; Lee, J.W.; Lim, S.D. The probiotic characteristics and GABA production of Lactobacillus plantarum K154 isolated from kimchi. Food Sci. Biotechnol. 2014, 23, 1951-1957. [CrossRef]

47. Lu, X.; Chen, Z.; Gu, Z.; Han, Y. Isolation of $\gamma$-aminobutyric acid-producing bacteria and optimization of fermentative medium. Biochem. Eng. J. 2008, 41, 48-52. [CrossRef]

48. Sa, H.D.; Park, J.Y.; Jeong, S.J.; Lee, K.W.; Kim, J.H. Characterization of glutamate decarboxylase (GAD) from Lactobacillus sakei A156 isolated from jeot-gal. J. Microbiol. Biotechnol. 2015, 25, 696-703. [CrossRef] [PubMed]

49. Yu, J.J.; Oh, S.H. $\gamma$-aminobutyric acid production and glutamate decarboxylase activity of Lactobacillus sakei OPK2-59 isolated from kimchi. Korean J. Microbiol. Biotechnol. 2011, 47, 316-322.

50. Cho, S.Y.; Park, M.J.; Kim, K.M.; Ryu, J.H.; Park, H.J. Production of high $\gamma$-aminobutyric acid (GABA) sour kimchi using lactic acid bacteria isolated from mukeunjee kimchi. Food Sci. Biotechnol. 2011, 20, 403-408. [CrossRef]

51. Cho, Y.R.; Chang, J.Y.; Chang, H.C. Production of $\gamma$-aminobutyric acid (GABA) by Lactobacillus buchneri isolated from kimchi and its neuroprotective effect on neuronal cells. J. Microbiol. Biotechnol. 2007, 17, 104-109.

52. Seo, M.J.; Lee, J.Y.; Nam, Y.D.; Lee, S.Y.; Park, S.L.; Yi, S.H.; Lim, S.I. Production of $\gamma$-aminobutyric acid by Lactobacillus brevis 340G isolated from kimchi and its application to skim milk. Food Eng. Prog. 2013, 17, 418-423. [CrossRef]

53. Seo, M.J.; Nam, Y.D.; Lee, S.Y.; Park, S.L.; Yi, S.H.; Lim, S.I. Expression and characterization of a glutamate decarboxylase from Lactobacillus brevis $877 \mathrm{G}$ producing $\gamma$-aminobutyric acid. Biosci. Biotechnol. Biochem. 2013, 77, 853-856. [CrossRef] [PubMed]

54. Kim, J.A.; Park, J.Y.; Kim, J.H. Characterization of the recombinant glutamate decarboxylase of Lactobacillus brevis G144 isolated from galchi jeotgal, a Korean salted and fermented seafood. Microbiol. Biotechnol. Lett. 2021, 49, 9-17. [CrossRef]

55. Lim, H.S.; Cha, I.T.; Roh, S.W.; Shin, H.H.; Seo, M.J. Enhanced production of gamma-aminobutyric acid by optimizing culture conditions of Lactobacillus brevis HYE1 isolated from kimchi, a Korean fermented food. J. Microbiol. Biotechnol. 2017, 27, 450-459. [CrossRef] [PubMed]

56. Binh, T.T.T.; Ju, W.T.; Jung, W.J.; Park, R.D. Optimization of $\gamma$-amino butyric acid production in a newly isolated Lactobacillus brevis. Biotechnol. Lett. 2014, 36, 93-98. [CrossRef] [PubMed]

57. $\mathrm{Wu}, \mathrm{Q}$.; Shah, N.P. Gas release-based prescreening combined with reversed-phase HPLC quantitation for efficient selection of high- $\gamma$-aminobutyric acid (GABA)-producing lactic acid bacteria. J. Dairy Sci. 2015, 98, 790-797. [CrossRef] [PubMed]

58. Lee, S.J.; Yao, Z.; Meng, Y.; Le, H.G.; Jeon, H.S.; Yoo, J.Y.; Kim, J.H. Isolation of $\gamma$-aminobutyric acid producing Lactobacillus brevis T118 from Sun-Tae Jeotgal and its glutamate decarboxylase gene cloning. J. Agric. Life Sci. 2020, 54, 85-92. [CrossRef]

59. Park, J.Y.; Jeong, S.J.; Kim, J.H. Characterization of a glutamate decarboxylase (GAD) gene from Lactobacillus zymae. Biotechnol. Lett. 2014, 36, 1791-1799. [CrossRef]

60. Jung, M.Y.; Kim, T.W.; Lee, C.; Kim, J.Y.; Song, H.S.; Kim, Y.B.; Ahn, S.W.; Kim, J.S.; Roh, S.W.; Lee, S.H. Role of jeotgal, a korean traditional fermented fish sauce, in microbial dynamics and metabolite profiles during kimchi fermentation. Food Chem. 2018, 265, 135-143. [CrossRef]

61. Lee, K.W.; Shim, J.M.; Yao, Z.; Kim, J.A.; Kim, J.H. Properties of kimchi fermented with GABA-producing lactic acid bacteria as a starter. J. Microbiol. Biotechnol. 2018, 28, 534-541. [CrossRef] [PubMed]

62. Fan, E.; Huang, J.; Hu, S.; Mei, L.; Yu, K. Cloning, sequencing and expression of a glutamate decarboxylase gene from the GABA-producing strain Lactobacillus brevis CGMCC 1306. Ann. Microbiol. 2012, 62, 689-698. [CrossRef]

63. Gong, L.; Ren, C.; Xu, Y. Deciphering the crucial roles of transcriptional regulator GadR on gamma-aminobutyric acid production and acid resistance in Lactobacillus brevis. Microb. Cell Factories 2019, 18, 108. [CrossRef] [PubMed] 
64. Hwang, H.; Lee, J.H. Characterization of arginine catabolism by lactic acid bacteria isolated from kimchi. Molecules 2018, 23, 3049. [CrossRef] [PubMed]

65. Qi, H.; Li, Y.; Yun, H.; Zhang, T.; Huang, Y.; Zhou, J.; Yan, H.; Wei, J.; Liu, Y.; Zhang, Z.; et al. Lactobacillus maintains healthy gut mucosa by producing L-ornithine. Commun. Biol. 2019, 2, 171. [CrossRef]

66. Majsnerowska, M.; Noens, E.E.; Lolkema, J.S. Arginine and citrulline catabolic pathways encoded by the arc gene cluster of Lactobacillus brevis ATCC 367. J. Bacteriol. 2018, 200, e00182-18. [CrossRef] [PubMed]

67. Noens, E.E.; Lolkema, J.S. Convergent evolution of the arginine deiminase pathway: The ArcD and ArcE arginine/ornithine exchangers. Microbiologyopen 2017, 6, e00412. [CrossRef]

68. Su, M.S.; Schlicht, S.; Gänzle, M.Z. Contribution of glutamate decarboxylase in Lactobacillus reuteri to acid resistance and persistence in sourdough fermentation. Microb. Cell Factories 2011, 10 (Suppl. S1), S8. [CrossRef]

69. Kang, B.K.; Cho, M.S.; Ahn, T.Y.; Lee, E.S.; Park, D.S. The influence of red pepper powder on the density of Weissella koreensis during kimchi fermentation. Sci. Rep. 2015, 5, 15445. [CrossRef] [PubMed]

70. Jung, S.; Lee, J.H. Red pepper powder is an essential factor for ornithine production in kimchi fermentation. LWT-Food Sci. Technol. 2021, 137, 110434. [CrossRef]

71. Park, J.E.; Oh, S.H.; Cha, Y.S. Lactobacillus brevis OPK-3 from kimchi prevents obesity and modulates the expression of adipogenic and pro-inflammatory genes in adipose tissue of diet-induced obese mice. Nutrients 2020, 12, 604. [CrossRef] [PubMed]

72. Mun, S.Y.; Moon, S.H.; Chang, H.C. Characterization of high-ornithine-producing Weissella koreensis DB1 isolated from kimchi and its application in rice bran fermentation as a starter culture. Foods 2020, 9, 1545. [CrossRef]

73. Yu, J.J.; Park, H.J.; Kim, S.G.; Oh, S.H. Isolation, identification, and characterization of Weissella strains with high ornithine producing capacity from kimchi. Korean J. Microbiol. 2009, 45, 339-345.

74. Mun, S.Y.; Chang, H.C. Characterization of Weissella koreensis SK isolated from kimchi fermented at low temperature (around $0{ }^{\circ} \mathrm{C}$ ) based on complete genome sequence and corresponding phenotype. Microorganisms 2020, 8, 1147. [CrossRef]

75. Park, J.A.; Tirupathi Pichiah, P.B.; Yu, J.J.; Oh, S.H.; Daily, J.W., III; Cha, Y.S. Anti-obesity effect of kimchi fermented with Weissella koreensis OK 1-6 as starter in high-fat diet-induced obese C57BL/6J mice. J. Appl. Microbiol. 2012, 113, 1507-1516. [CrossRef]

76. Wisselink, H.W.; Weusthuis, R.A.; Eggink, G.; Hugenholtz, J.; Grobben, G.J. Mannitol production by lactic acid bacteria: A review. Int. Dairy J. 2002, 12, 151-161. [CrossRef]

77. Park, Y.C.; Oh, E.J.; Jo, J.H.; Jin, Y.S.; Seo, J.H. Recent advances in biological production of sugar alcohols. Curr. Opin. Biotechnol. 2016, 37, 105-113. [CrossRef] [PubMed]

78. Rice, T.; Sahin, A.W.; Lynch, K.M.; Arendt, E.K.; Coffey, A. Isolation, characterisation and exploitation of lactic acid bacteria capable of efficient conversion of sugars to mannitol. Int. J. Food Microbiol. 2020, 321, 108546. [CrossRef]

79. Helanto, M.; Aarnikunnas, J.; von Weymarn, N.; Airaksinen, U.; Palva, A.; Leisola, M. Improved mannitol production by a random mutant of Leuconostoc pseudomesenteroides. J. Biotechnol. 2005, 116, 283-294. [CrossRef]

80. Wisselink, H.W.; Moers, A.P.H.A.; Mars, A.E.; Hoefnagel, M.H.N.; de Vos, W.M.; Hugenholtz, J. Overproduction of heterologous mannitol 1-phosphatase: A key factor for engineering mannitol production by Lactococcus lactis. Appl. Environ. Microbiol. 2005, 71, 1507-1514. [CrossRef]

81. Zhang, M.; Gu, L.; Cheng, C.; Ma, J.; Xin, F.; Liu, J.; Wu, H.; Jiang, M. Recent advances in microbial production of mannitol: Utilization of low-cost substrates, strain development and regulation strategies. World J. Microbiol. Biotechnol. 2018, 34, 49. [CrossRef] [PubMed]

82. Saha, B.C.; Racine, F.M. Biotechnological production of mannitol and its application. Appl. Microbial. Biotechnol. 2011, 89, 879-891. [CrossRef]

83. Dai, Y.; Meng, Q.; Mu, W.; Zhang, T. Recent advances in the applications and biotechnological production of mannitol. J. Funct. Foods 2017, 36, 404-409. [CrossRef]

84. Martău, G.A.; Coman, V.; Vodnar, D.C. Recent advances in the biotechnological production of erythritol and mannitol. Crit. Rev. Biotechnol. 2020, 40, 608-622. [CrossRef] [PubMed]

85. Otgonbayar, G.E.; Eom, H.J.; Kim, B.S.; Ko, J.H.; Han, N.S. Mannitol production by Leuconostoc citrum KACC91348P isolated from kimchi. J. Microbiol. Biotechnol. 2011, 21, 968-971. [CrossRef] [PubMed]

86. Jung, J.Y.; Lee, S.H.; Lee, H.J.; Seo, H.Y.; Park, W.S.; Jeon, C.O. Effects of Leuconostoc mesenteroides starter cultures on microbial communities and metabolites during kimchi fermentation. Int. J. Food Microbiol. 2012, 153, 378-387. [CrossRef] [PubMed]

87. Kim, M.J.; Lee, H.W.; Lee, M.E.; Roh, S.W.; Kim, T.W. Mixed starter of Lactococcus lactis and Leuconostoc citreum for extending kimchi shelf-life. J. Microbiol. Biotechnol. 2019, 57, 479-484. [CrossRef] [PubMed]

88. Du, R.; Xing, H.; Yang, Y.; Jiang, H.; Zhou, Z.; Han, Y. Optimization, purification and structural characterization of a dextran produced by L. mesenteroides isolated from Chinese sauerkraut. Carbohydr. Polym. 2017, 174, 409-416. [CrossRef]

89. Kleerebezem, M.; Hols, P.; Bernard, E.; Rolain, T.; Zhou, M.; Siezen, R.J.; Bron, P.A. The extracellular biology of the lactobacilli. FEMS Microbiol. Rev. 2010, 34, 199-230. [CrossRef]

90. Chen, F.; Huang, G.; Huang, H. Preparation and application of dextran and its derivatives as carriers. Int. J. Biol. Macromol. 2020, 145, 827-834. [CrossRef]

91. Daba, G.M.; Elnahas, M.O.; Elkhateeb, W.A. Contribution of exopolysaccharides from lactic acid bacteria as biotechnological tools in food, pharmaceutical, and medical applications. Int. J. Biolog. Macromol. 2021, 173, 79-89. [CrossRef] [PubMed] 
92. Patel, S.; Majumder, A.; Goyal, A. Potentials of exopolysaccharides from lactic acid bacteria. Indian J. Microbiol. $2012,52,3-12$. [CrossRef]

93. Pérez-Ramos, A.; Nácher-Vázquez, M.; Notararigo, S.; López, P.; Mohedano, M.L. Current and future applications of bacterial extracellular polysaccharides. In Probiotics, Prebiotics, and Synbiotics; Preedy, V.R., Watson, R.R., Eds.; Elsevier: Oxford, UK, 2015; pp. 329-344. [CrossRef]

94. Angelin, J.; Kavitha, M. Exopolysaccharides from probiotic bacteria and their health potential. Int. J. Biolog. Macromol. 2020, 162, 853-865. [CrossRef]

95. Wu, J.; Zhang, Y.; Ye, L.; Wang, C. The anti-cancer effects and mechanisms of lactic acid bacteria exopolysaccharides in vitro: A review. Carbohydr. Polym. 2021, 253, 117308. [CrossRef] [PubMed]

96. Kim, K.; Lee, G.; Thanh, H.D.; Kim, J.H.; Konkit, M.; Yoon, S.; Park, M.; Yang, S.; Park, E.; Kim, W. Exopolysaccharide from Lactobacillus plantarum LRCC5310 offers protection against rotavirus-induced diarrhea and regulates inflammatory response. J. Dairy Sci. 2018, 101, 5702-5712. [CrossRef] [PubMed]

97. Kook, S.Y.; Lee, Y.; Jeong, E.C.; Kim, S. Immunomodulatory effects of exopolysaccharides produced by Bacillus licheniformis and Leuconostoc mesenteroides isolated from Korean kimchi. J. Funct. Foods 2019, 54, 211-219. [CrossRef]

98. Zarour, K.; Llamas, M.G.; Prieto, A.; Rúas-Madiedo, P.; Dueñas, M.T.; de Palencia, P.F.; Aznar, R.; Kihal, M.; López, P. Rheology and bioactivity of high molecular weight dextrans synthesised by lactic acid bacteria. Carbohydr. Polym. 2017, 174, 646-657. [CrossRef] [PubMed]

99. Yu, H.S.; Jang, H.J.; Lee, N.K.; Paik, H.D. Evaluation of the probiotic characteristics and prophylactic potential of Weissella cibaria strains isolated from kimchi. LWT-Food Sci. Technol. 2019, 112, 108229. [CrossRef]

100. Yadav, R.; Singh, P.K.; Shukla, P. Metabolic engineering for probiotics and their genome-wide expression profiling. Curr. Protein Pept. Sci. 2018, 19, 68-74. [CrossRef]

101. Li, N.; Wang, Y.; Zhu, P.; Liu, Z.; Guo, B.; Ren, J. Improvement of exopolysaccharide production in Lactobacillus casei LC2W by overexpression of NADH oxidase gene. Microbiol. Res. 2015, 171, 73-77. [CrossRef]

102. Sharma, A.; Gupta, G.; Ahmad, T.; Kaur, B.; Hakeem, K.R. Tailoring cellular metabolism in lactic acid bacteria through metabolic engineering. J. Microbiol. Methods 2020, 170, 105862. [CrossRef]

103. Axel, C.; Brosnan, B.; Zannini, E.; Peyer, L.C.; Furey, A.; Coffey, A.; Arendt, E. Antifungal activities of three different Lactobacillus species and their production of antifungal carboxylic acids in wheat sourdough. Appl. Microbiol. Biotechnol. 2016, 100, 1701-1711. [CrossRef] [PubMed]

104. Sun, D.; Li, H.; Song, D.; Zhang, L.; Zhao, X.; Xu, X. Genome, transcriptome and fermentation analyses of Lactobacillus plantarum LY-78 provide new insights into the mechanism of phenyllactate biosynthesis in lactic acid bacteria. Biochem. Biophys. Res. Commun. 2019, 519, 351-357. [CrossRef]

105. Park, B.; Hwang, H.; Chang, J.; Hong, S.W.; Lee, S.H.; Jung, M.Y.; Sohn, S.O.; Park, H.W.; Lee, J.H. Identification of 2hydroxyisocaproic acid production in lactic acid bacteria and evaluation of microbial dynamics during kimchi ripening. Sci. Rep. 2017, 7, 10904. [CrossRef] [PubMed]

106. Vermeulen, N.; Gaänzle, M.G.; Vogel, R.F. Influence of peptide supply and cosubstrates on phenylalanine metabolism of Lactobacillus sanfranciscensis DSM20451T and Lactobacillus plantarum TMW1.468. J. Agric. Food Chem. 2006, 54, 3832-3839. [CrossRef]

107. Zheng, R.; Zhao, T.; Hung, Y.C.; Adhikari, K. Evaluation of bactericidal effects of phenyllactic acid on Escherichia coli O157:H7 and Salmonella Typhimurium on beef meat. J. Food Prot. 2019, 82, 2016-2022. [CrossRef] [PubMed]

108. Mero, A.A.; Ojala, T.; Hulmi, J.J.; Puurtinen, R.; Kalira, T.A.M.; Seppälä, T. Effects of alpha-hydroxy-isocaproic acid on body composition, DOMS and performance in athletes. J. Int. Soc. Sports Nutr. 2010, 7, 1. [CrossRef] [PubMed]

109. Teixera, F.; Matias, C.N.; Monteiro, C.P.; Valamatos, M.J.; Reis, J.F.; Tavares, F.; Batista, A.; Domingos, C.; Alves, F.; Sardinha, L.B.; et al. Leucine metabolites do not enhance training-induced performance or muscle thickness. Med. Sci. Sports Exerc. 2019, 51, 56-64. [CrossRef]

110. Fujita, T.; Nguyen, H.D.; Ito, T.; Zhou, S.; Osada, L.; Tateyama, S.; Kaneko, T.; Takaya, N. Microbial monomers custom-synthesized to build true bio-derived aromatic polymers. Appl. Microbiol. Biotechnol. 2013, 97, 8887-8894. [CrossRef] [PubMed]

111. Ilavenil, S.; Kim, D.H.; Arasu, M.V.; Srigopalram, S.; Sivanesan, R.; Choi, K.C. Phenyllactic acid from Lactobacillus plantarum promotes adipogenic activity in 3T3-L1 adipocyte via up-regulation of PPAR- $\gamma 2$. Molecules 2015, 20, 15359-15373. [CrossRef]

112. Peters, A.; Krumbholz, P.; Jäger, E.; Heintz-Buschart, A.; Cakir, M.V.; Rothemund, S.; Gaudl, A.; Ceglarek, U.; Schőneberg, T.; Stäubert, C. Metabolites of lactic acid bacteria present in fermented foods are highly potent agonists of human hydroxycarboxylic acid receptor 3. PLoS Genet. 2019, 15. [CrossRef]

113. Hwang, H.; Lee, J.H. Evaluation of metabolites derived from lactic acid bacteria isolated from kimchi. In Chemistry of Korean Foods and Beverages; Do, C.H., Rimando, A.M., Kim, Y., Eds.; ACS Publications: Washington, DC, USA, 2019; Volume 1303, pp. 3-10. [CrossRef]

114. Sakko, M.; Tjäderhane, L.; Sorsa, T.; Hietala, P.; Rautemaa, R. 2-Hydroxyisocaproic acid is bactericidal in human dental root canals ex vivo. Int. Endod. J. 2017, 50, 455-463. [CrossRef] [PubMed]

115. Nieminen, M.T.; Novak-Frazer, L.; Rautemaa, V.; Rajendran, R.; Sorsa, T.; Ramage, G.; Bowyer, P.; Rautemaa, R. A novel antifungal is active against Candida albicans biofilms and inhibits mutagenic acetaldehyde production in vitro. PLoS ONE 2014, 9, e97864. [CrossRef] 
116. Sakko, M.; Moore, C.; Novak-Frazer, L.; Rautemaa, V.; Sorsa, T.; Hietala, P.; Järvinen, A.; Bowyer, P.; Tjäderhane, L.; Rautemaa, R. 2-Hydroxyisocaproic acid is fungicidal for Candida and Aspergillus species. Mycoses 2014, 57, 214. [CrossRef] [PubMed]

117. Filannino, P.; Cagno, R.D.; Gobbetti, M. Metabolic and functional paths of lactic acid bacteria in plant foods: Get out of the labyrinth. Curr. Opin. Biotechnol. 2018, 49, 64-72. [CrossRef] [PubMed]

118. Han, Y.; Kim, B.; Ban, J.; Lee, J.; Kim, B.J.; Choi, B.S.; Hwang, S.; Ahn, K.; Kim, J. A randomized trial of Lactobacillus plantarum CJLP133 for the treatment of atopic dermatitis. Pediatr. Allergy Immunol. 2012, 23, 667-673. [CrossRef] [PubMed] 